\title{
The Oxidation of Hydrazobenzene Catalyzed by Cobalt Complexes in Nonaqueous Solvents
}

\author{
Stephen S. B. Kim," Roger B. Hommer, and Roderick D. Cannon ${ }^{\dagger}$ \\ Department of Chemistry. University of Ulsan. Ulsan 690, P.O. Box 18. Korea. 'E-mail: sbkim41@hotmail.com \\ "School of Chemical Sciences. University of East Anglia, Nonvich, NR4 7TJ. England, U.K. \\ Received August 15, 2005
}

\begin{abstract}
The oxidation of hydrazobenzene by molecular oxygen in the polar solvent methanol is catalysed by a Schiff's base complex $\mathrm{Co}(3 \mathrm{MeO}$ salen) which is a synthetic oxygen carrier. The products are trans-azobenzene and water. The rate of the reaction has been studied spectrophotometrically and the rate law established. $\Lambda$ mechanism unvolving a ternary complex of catalyst, hydrazobenzene and molecular oxygen has been proposed. The kinetic studies show that a ternary complex CoL $\cdot \mathrm{I}_{2} \Lambda \mathrm{B}-\mathrm{O}_{2}$ is involved in the rate determining step. The reactions are summarised in a catalytic cycle. The kinetic data suggest that a tenary complex involving Co (3MeOsalen), triphenyl-phosphine and molecular oxygen is catalytically acive species but at higher triphenylphosphine concentrations the catalyst becomes inactive. The destruction of the catalytic activity could be due to the catalyst becoming coordunated with triphenyl phosphine at both $\mathrm{z}$ axis sites of the complex eg. Co (3MeOsalen) $\left(\mathrm{PPh}_{\bar{z}}\right)_{2}$.
\end{abstract}

Key Words : Catalytic cycle, Cobalt complexes, Hydrazobenzene, Axial ligands, Reaction mechanisms

\section{Introduction}

It has been known since the observation of Pfeiffer and his co-workers ${ }^{1}$ in 1933 that Cobalt(II) Schiff's base complexes e.g. N. N-thylenebis(salicylideneiminato)-cobalt(II), Co(salen), Figure 1, form reversible complexes with oxygen. Tsumaki ${ }^{2}$ in 1938 demonstrated that the colour change observed upon exposing $C o$ (salen) to air as due to the reversible oxygenation of complexes, as shown in equations (1) and (2).

Although molecular oxygen reacts reversibly with some metal complexes, there are certain complexes fomed

$$
\begin{aligned}
\mathrm{Co}(\text { salen })-\mathrm{O}_{2} & \rightleftharpoons \mathrm{Co}(\text { salen })_{2} \\
2 \mathrm{Co}(\text { salen })-\mathrm{O}_{2} & =\mathrm{Co}(\text { salen })_{2} \mathrm{O}_{2}
\end{aligned}
$$

ireversibly such as $\left.\left[\left(\mathrm{CO}\left(\mathrm{NH}_{3}\right),\right)_{2} \mathrm{O}_{2}\right](\mathrm{SCN})_{+}\right]^{3}$

A study of synthetic dioxygen complexes is important for understanding the bonding of dioxygen to transition metal complexes and the effect of this bonding upon the reactivity of dioxygen toward other substrates.

There has been considerable recent interest in these compounds because of their relationship to the natural ironcontaining oxygen caniers hemoglobin and myoglobin. ${ }^{3}$ Hemoglobin and myoglobin consist of an iron-porphyrin complex, the haem group, embedded in the protein which provides one axial ligand, an imidazole group, to the iron. On oxygenation the sixth coordination site of the iron accepts the dioxygen ligand.

Thus the ligand field about the iron in oxyhemoglobin is approximately octahedral. ${ }^{4}$ Reversible dioxygen complexes are utilised in living organism for the transport and storage. of molecular oxygen. Dioxygen binding also occurs in enzymes which catalyse oxidation processes. ${ }^{6}$

Cobalt(II) Schiff's base complexes are square planner with a low spin $d^{7}$ electron configuration. The binding of an axial, fifth ligand leads to a ground state with the unpaired electron in the $\mathrm{d}_{\mathrm{z} 2}$ orbital. This electron configuration is a necessary prerequisite for the binding of dioxygen. Drago and Corden, ${ }^{8}$ in their spin-pairing model for the binding of dioxygen, presented evidence that the odd electron in the oxygenated complex is in the dioxygen $\pi$ orbital, but that the extent of electron transfer from cobalt to oxygen is dependent on the nature of the equatorial and axial ligands. In the extreme case of complete electron transfer the complex could be formulated as cobalt(III)-superoxide.

The change in the electronic structure of oxygen from the relatively unreactive triplet ground state to a doublet coordinated species, with a weakened $\mathrm{O}-\mathrm{O}$ bond bearing fractional negative charge, could be expected to enhance the reactivity of oxygen in radical or nucleophilic reactions.

In recent years the catalytic behavior of dioxygen complexes, Cobalt(II) Schiff base oxygen carrier complexes have been studied by both academics and industrialist. ${ }^{6}$ Cobalt(II) Schiff's base complexes with added axial ligands have been shown to catalyse the oxidation by oxygen of secondary alcohols ${ }^{9}$ to ketones, and of phenols ${ }^{10}$ to quinones.

Cobalt complexes with salen or polyamines and related ligands have been employed as catalysts. ${ }^{11.12}$ Savitskii ${ }^{9}$ has made a kinetic study of the catalytic oxidation of isopropanol to acetone using initial reaction rates from oxygen consumption, and they have derived the rate law. They have also published a kinetic study of the catalytic oxidation of hydroquinone ${ }^{13}$ in presence of $\mathrm{Co}(\mathrm{salen})$ in dimethylacetamide (DMA). They identified the main product of the oxidation of hydroquinone as $p$-benzoquinone. Nishinaga ${ }^{11}$ indicated that a better model for natural systems is the catalytic double bond oxidation. ${ }^{3.11}$ Nishinaga $e t a l^{1+}$ have 
reported that the oxidation of 2,6-di-t-butylphenols by fivecoordinate Co(II)Schiff-base complexes, for example cobalt(II)bisisalicylideneamino)propylamine, has been found to result in the formation of peroxyquinolatocobalt(III) complexes. Drago et al. ${ }^{10.15}$ began a kinetic investigation to provide insight into both the oxidation of 2,6-dimethylphenol and the deactivation of the catalyst CoSMDPT, cobalt(tI) (3-salicylideneaminopropyl)methylamine. They also reported the catalytic oxidation ${ }^{16}$ of olefins by molecular oxygen and by using CoSalMDPT, cobalt(II)-bis(salicylidene-iminopropyl)methylamine. It is interesting to note that the catalyst CoSalMDPT demonstrates some substrate selectivity, oxidising linear olefins but not cyclohexane, and the reaction rate is independent of $O_{2}$ pressure.

The structually related bis(dimethylglyoximato)cobalt(II) has been reported to catalyse the oxidation of hydrazoberzene to azobenzene in the presence of triphenylphosphine. ${ }^{17}$ Kinetic studies 9.10 have shown that in the oxidation of alcohols and phenols the transition state is a temary complex of dioxygen, cobalt catalyst (including axial base) and substrate. Thus the reactions resemble an enzyme-catalysed process in which the two substrates, dioxygen and the organic molecule, are brought together by the catalyst.

In this paper we show that the oxidation of hydrabenzene catalysed by $\mathrm{Co}(3 \mathrm{MeOsalen})$, Figure 1, follows a similar kinetic scheme, providing evidence of saturation of the catalyst by the substrate as an enzyme catalysed reaction. Autoxidation of hydrabenzene was first described in 1901 by Manchot and Herzog. ${ }^{18}$ This, and later work ${ }^{19.20}$ has shown that the products are trans-azoberzene and hydrogen peroxide with the reaction first order in hydrazobenzene and oxygen.

\section{Results and Discussion}

Studies of the oxidation of organic substrates catalysed by transition metal complexes have been focussed on three main themes: (1) the discovery of new oxidation catalysts and new catalytic oxidation reactions, (2) the elucidation of mechanisms through kinetic studies, and (3) the tailoring of the catalyst and reaction conditions for maximum catalytic activity. ${ }^{21}$ Our work concentrates on the second of these.

Co(II) (3MeOsalen) has been used as a catalyst in the oxdation of hydrazoberzene $\left(\mathrm{H}_{2} \mathrm{AB}\right)$. Hydrazobenzene is

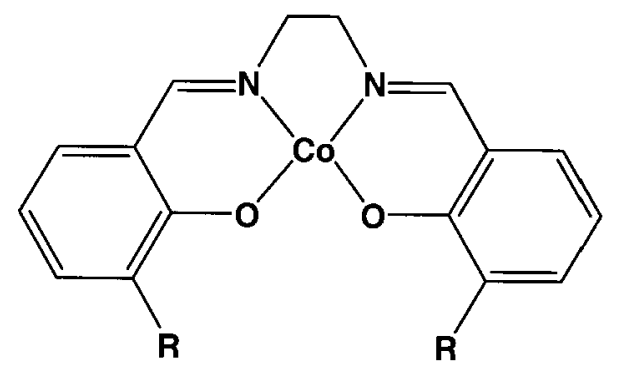

Figure 1. Cobalt(II)-Schiff base complexes, e.g. $N_{\text {. }}$-ethylencbis (salicylideneitrinato)-cobalt (II), $\mathrm{Co}^{\pi}$ (salen), R = H, Co(salen); R = $\mathrm{CH}_{s} \mathrm{O}, \mathrm{Co}$ (3MeOsalen). catalytically oxidised to azobenzene $(\mathrm{AB})$ by $\mathrm{L} \cdot \mathrm{Co}(3 \mathrm{Me}$ Osalen $) \mathrm{O}_{2}(\mathrm{~L}=$ Ligand $)$ in the polar solvent, methanol. Azobenzene has two isomers ( $c i s$ and trans), thus the product of oxidation may provide stereochemical infomation about the reaction pathway. Hydrazobenzene is readily autoxidised to azobenzene and hydrogen peroxide, ${ }^{18}$ and there is a possibility that the hydrogen peroxide produced may also oxidise hydrazobenzene. The rates of the oxidation of hydrazobenzene are measured under $\mathrm{O}_{2}$ and air saturation at the $315 \mathrm{~nm}$ or $437 \mathrm{~mm}$ absorption bands of azobenzene.

The solvent methanol has a high polarity and the oxidation reaction may be carried out with or without an axial ligand. However, ligands were employed to observe their effect on the catalytic activity.

The results and discussion have been split into two parts : the kinetics of the $\mathrm{Co}$ (II)(3MeOsalen) catalysed oxidation of hydrazobenzene, and the reaction mechanism of hydrazobenzene oxidation.

The term autoxidation ${ }^{2-}$ is applied generally to oxidations which can be effected by free oxygen (e.g. by air) at moderate temperatures and may be contrasted with the rapid processes of combustion which require high temperatures. It has long been known that autoxidations are promoted by light ${ }^{2 \hat{3}}$ and by small quantities of many catalysts.

The autoxidation of hydrazobenzene has already been well studied. ${ }^{18}$ Hydrazobemzene is readily autoxidised in ethanol with the formation of azobenzene and hydrogen peroxide. ${ }^{19}$ They found that in an alcololic solution the reaction is practically quantitative, equation (3).

$$
\mathrm{C}_{6} \mathrm{H}_{5} \mathrm{NHNHC}_{6} \mathrm{H}_{5}+\mathrm{O}_{2} \stackrel{\mathrm{EtOH}}{\longrightarrow} \mathrm{C}_{6} \mathrm{H}_{5} \mathrm{~N}^{2} \mathrm{NC}_{6} \mathrm{H}_{5}+\mathrm{H}_{2} \mathrm{O}_{2}
$$

The rate of the autoxidation of hydrazobemzene in methanol was found to be first order in substrate at room temperature. ${ }^{21}$ Hinshelwood and Blackadder ${ }^{24}$ reported that autoxidation of hydrzobenzene in alkaline solution ( $44 \%$ ethanol) containing oxygen was "a spontaneous reaction of first order with respect to hydrazobenzene". The rate of reaction became independent of oxygen once a concentration about $5 \%$ oxygen had been exceeded in the atmosphere to which the solution had been exposed. Savitskii and Nelyubin ${ }^{13}$ demonstrated that the rate of $\mathrm{O}_{2}$ consumption in the oxidation of hydroquinone is independent of oxygen pressure at 1 atmosphere.

When the initial rate $\mathrm{R}_{\mathrm{a}}$ is plotted against the hydrazobenzene concentration, the plots are linear, Figure 2 . We have demonstrated that autoxidation of hydrazobemzene in anhydrous methanol was found to be first order in $\mathrm{O}_{2}$ or air, Table 1. The rate constants of the reaction mixture were caclulated to be $3.85 \times 10^{-6} \mathrm{sec}^{-1}$ in the $\mathrm{O}_{2}$ saturated methanol and $1.98 \times 10^{-6} \mathrm{sec}^{-1}$ in the air saturated methanol. The rates of the autoxidation are used to find the initial rates in the catalysed reaction in Table 2 and 3.

The product azobemzene has two isomers, cis- and transazobenzene..$^{25}$ Trans-azo-benzene is found to be planar, or at least peri-planar, while the phenyl rings of the cis-isomer are 


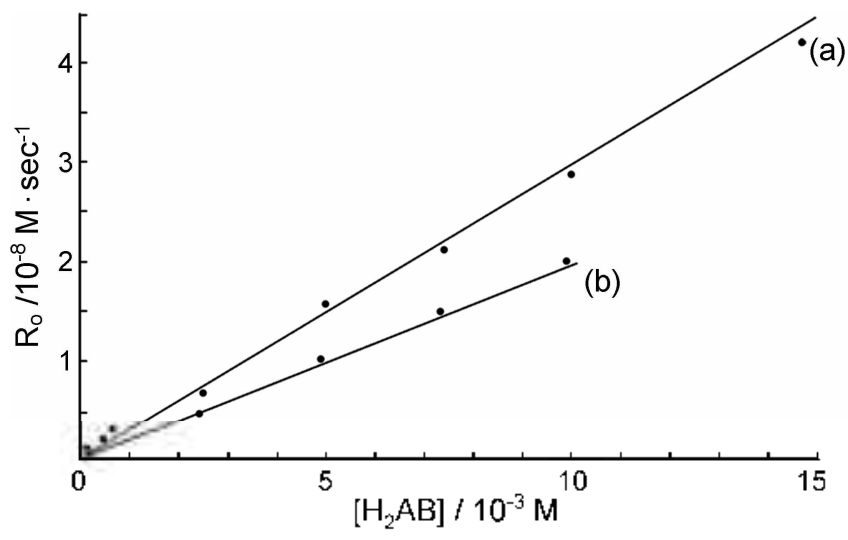

Figure 2. Plots of initial tates $\mathrm{R}_{1}$ against $\left[\mathrm{H}_{2} \mathrm{AB}\right] . \mathrm{O}_{2}$ (a) and air (b) saluraled methanol al $25.0^{\circ} \mathrm{C}, \lambda=315 \mathrm{~nm}$ and $437 \mathrm{~nm}$. The rate constants are $\mathrm{k}\left(\mathrm{O}_{2}\right)-3.85 \times 10^{46} \mathrm{sec}{ }^{1}$ and $\mathrm{k}(\mathrm{air})-1.98 \times 10^{6} \mathrm{sec} ?$

Tablc 1. Effect of varing hydrazobenzene concentration, $\left[\mathrm{H}_{2} \mathrm{AB}\right]$ on the autoxidation of hydrazobenzene in $\mathrm{O}_{2}$ and air salurated melhanol at $25,0^{\circ} \mathrm{C}$

\begin{tabular}{|c|c|c|c|c|c|}
\hline \multirow[b]{2}{*}{ NO. } & \multirow{2}{*}{$\begin{array}{l}{\left[\mathrm{H}_{2} \mathrm{AB}\right]} \\
110^{-3} \mathrm{M}\end{array}$} & \multicolumn{2}{|c|}{$\mathrm{O}_{2}$ saturated methanol } & \multicolumn{2}{|c|}{ air saturated methanol } \\
\hline & & $\begin{array}{c}(\mathrm{dA} / \mathrm{d} t) \\
/ 10^{-5} \mathrm{sec}^{-1}\end{array}$ & $\begin{array}{l}\mathrm{R} / 10^{-8} \\
\mathrm{sec}^{-1}\end{array}$ & $\begin{array}{c}(\mathrm{dA} / \mathrm{d} 1)_{0} \\
/ 10^{-5} \mathrm{sec}^{-1}\end{array}$ & $\begin{array}{l}\mathrm{R}_{0} / 10^{-\bar{x}} \\
\mathrm{sec}^{-1}\end{array}$ \\
\hline l & 0.102 & 0.667 & 0.0469 & & \\
\hline 2 & 0.388 & 2.29 & $0.161^{\prime \prime}$ & & \\
\hline 3 & 0.411 & 3.05 & $0.215^{5}$ & & \\
\hline 4 & 2.45 & 10.0 & 0.704 & 7.02 & 0.494 \\
\hline 5 & 4.90 & 22.6 & 1.59 & 14.0 & 0.986 \\
\hline 6 & 7.35 & 30.1 & 2.12 & 21.1 & 1.49 \\
\hline 7 & 9.80 & 41.4 & 2.91 & 28.1 & 1.98 \\
\hline 8 & 14.7 & 60.0 & 4.22 & & \\
\hline
\end{tabular}

"From Table 7 , "From Table $8, \lambda \quad 315 \mathrm{~mm}\left(\varepsilon_{i 15} \quad 1.61 \times 10^{2} \mathrm{M}^{-1} \mathrm{~cm}^{-1}\right.$ (No, l-3) and $\lambda=437 \mathrm{~nm}\left(\varepsilon_{1: 7}=5.09 \times 10^{\circ} \mathrm{M}^{-1} \mathrm{~cm}^{-1}(\mathrm{No}, 48) \cdot \mathrm{A} \varepsilon^{-1}=\right.$ $7.04 \times 10^{-5} \mathrm{M} \cdot \mathrm{cm} . \mathrm{R}_{\mathrm{w}}=\mathrm{A} .515^{-1} \cdot(\mathrm{d} \Lambda / \mathrm{d} t) \ldots$

Table 2. Effect of varing hydrazobenzene concentration, $\left[\mathrm{H}_{2} \mathrm{AB}\right]$ on the oxidation of hydrazobenzene in $\mathrm{O}_{2}$ salurated methanol at $25.0^{\circ} \mathrm{C}$

\begin{tabular}{|c|c|c|c|c|c|c|}
\hline \multicolumn{2}{|c|}{$[\mathrm{I}, \mathrm{AB}] /(\mathrm{dA} / \mathrm{d} \mathrm{d})_{0}$} & \multirow{2}{*}{$\begin{array}{l}\mathrm{R}_{10}{ }^{\prime \prime} / 10 \\
\mathrm{M} \cdot \mathrm{sec}^{\prime}\end{array}$} & \multirow{2}{*}{$\begin{array}{l}\mathrm{R}_{0}^{b}: 10^{8} \\
\mathrm{M} \cdot \mathrm{sec}{ }^{\prime}\end{array}$} & \multirow{2}{*}{$\begin{array}{l}\mathrm{R}_{0} / 10^{7} \\
\mathrm{M} \cdot \mathrm{sec}^{1}\end{array}$} & \multicolumn{2}{|c|}{$k_{k 1 .} / 10^{\prime}\left[\mathrm{l}_{2} \mathrm{AB}\right]^{\prime}$} \\
\hline $10^{3} \mathrm{M}$ & $10^{3} \sec { }^{\prime}$ & & & & $\mathrm{sec}$ & $10^{2} \mathrm{M}^{\prime}$ \\
\hline 1.81 & 3.11 & 2.19 & 0.550 & 2.13 & 3.49 & 5.52 \\
\hline 3.61 & 5.29 & 3.73 & 1.07 & 3.62 & 2.05 & 2.77 \\
\hline 7.22 & 9.45 & 6.65 & 2.15 & 6.44 & 1.15 & 1.39 \\
\hline 9.03 & 12.0 & 8.47 & 2.67 & 8.20 & 0.906 & 1.11 \\
\hline 10.8 & 13.0 & 9.18 & 3.18 & 8.86 & 0.839 & 0.923 \\
\hline 12.6 & 13.6 & 9.58 & 3.71 & 9.21 & 0.807 & 0.791 \\
\hline 14.4 & 14.9 & 10.5 & 4.23 & 10.1 & 0.734 & 0.693 \\
\hline
\end{tabular}

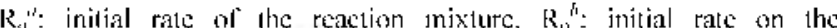
autoxidation of $I_{2} A B$ (Irom Figure 2), $R_{0,}=R_{0}{ }^{\prime \prime}-R_{10}{ }^{\prime \prime}, k_{10}{ }^{\prime}=$ $\mid \operatorname{Co}\left(3 \mathrm{MeO}\right.$ salen) $\left|R_{\mathrm{R}} ;\right| \operatorname{Co}(3 \mathrm{MeO}$ salen $) \mid=7.43 \times 10^{-6} \mathrm{M}, \lambda=315 \mathrm{~nm}$ $\left(\varepsilon(1 \mathrm{AB}) \quad 1.89 \times 10^{3} \mathrm{M}^{-1} \mathrm{~cm}^{-1}, \varepsilon(\mathrm{AB}) \quad 1.61 \times 10^{4} \mathrm{M}^{-1} \mathrm{~cm}^{-1}\right), \mathrm{R}$ $A \varepsilon^{-}:(\mathrm{d} \Lambda / \mathrm{dt}) \div \mathrm{As} \mathrm{c}^{-1}=7.04 \times 10^{-5} \mathrm{M} \cdot \mathrm{cm}$

twisted (by $56^{17}$ ) out of the plane, Figure 3.7rans-azobenzene has been calculated (by the self consistent field (SCF) method) to be more stable by $43.5 \mathrm{~K} \cdot \mathrm{J} \cdot \mathrm{mol}^{-1}\left(10.4 \mathrm{Kcal}^{\prime} \cdot \mathrm{mol}^{-1}\right)$ than the cis-isomer, which is in good agreement with the
Table 3. Effect of varing hydrazobenzene concentration, $\left[\mathrm{H}_{2} \mathrm{AB}\right]$ on the oxidation of hydrazobenzene in air salurated methanol at $25.0^{\circ} \mathrm{C}$

\begin{tabular}{|c|c|c|c|c|c|c|}
\hline $\begin{array}{c}{\left[\mathrm{H}_{2} \mathrm{AB}\right]} \\
10^{3} \mathrm{M}\end{array}$ & $\begin{array}{l}(\mathrm{dA} / \mathrm{dl})_{\mathrm{c} /} \\
10^{3} \mathrm{sec}\end{array}$ & $\begin{array}{l}\mathrm{R}_{\mathrm{th}_{1}} / 10^{-7} \\
\mathrm{M} \cdot \mathrm{sec}\end{array}$ & $\begin{array}{l}\mathrm{R}^{h}{ }_{1} / 10^{-8} \\
\mathrm{M} \cdot \sec { }^{\prime}\end{array}$ & $\begin{array}{l}\mathrm{R}_{0} / 10^{-7} \\
\mathrm{M} \cdot \mathrm{scc}^{\prime}\end{array}$ & $\begin{array}{c}k_{(1 \cdot-1} 10 \\
\sec \end{array}$ & $\begin{array}{c}{\left[\mathrm{H}_{2} \mathrm{AB}\right]^{-1}} \\
10^{2} \mathrm{M}\end{array}$ \\
\hline 1.16 & 0.619 & 0.436 & 0.230 & 0.413 & 18.0 & 8.62 \\
\hline 2.32 & 1.24 & 0.871 & 0.470 & 0.824 & 9.02 & 4.31 \\
\hline 3.48 & 1.75 & 1.23 & 0.700 & 1.16 & 6.41 & 2.87 \\
\hline 4.56 & 2.30 & 1.62 & 0.910 & 1.53 & 4.86 & 2.19 \\
\hline 5.70 & 2.93 & 2.06 & 1.15 & 1.95 & 3.81 & 1.75 \\
\hline 6.84 & 3.25 & 2.29 & 1.37 & 2.15 & 3.46 & 1.46 \\
\hline 7.98 & 3.85 & 2.71 & 1.60 & 2.55 & 2.91 & 1.25 \\
\hline 9.12 & 4.33 & 3.05 & 1.83 & 2.87 & 2.59 & 1.09 \\
\hline 10.3 & 4.93 & 3.47 & 2.05 & 3.26 & 2.28 & 0.975 \\
\hline
\end{tabular}

$R_{4}$, : : initial rate of the reaction mixture, $R_{,}$, : initial rate on the

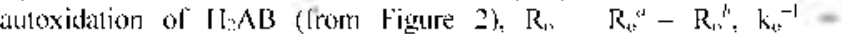
$[\mathrm{Co}(3 \mathrm{McOsalen})] / R_{1 \mathrm{t}}:[\mathrm{Co}(3 \mathrm{McOsalen})]=7.43 \times 10^{-6} \mathrm{M} . \lambda_{*}=315 \mathrm{~nm}$ $\left(\varepsilon(1 \mathrm{l}, \Delta B)=1.89 \times 10^{3} \mathrm{M}^{-} \cdot \mathrm{cm}^{-1}, \varepsilon(A B)=1.61 \times 10^{\circ} \mathrm{M}^{-1} \cdot \mathrm{cm}^{-1}\right), \mathrm{R}_{0}=$ $\Delta \varepsilon^{\prime}(\mathrm{d} \Lambda / \mathrm{dt}), \Delta \varepsilon \cdot=7.04 \times 10^{3} \mathrm{M}^{\prime} \mathrm{cm}$.
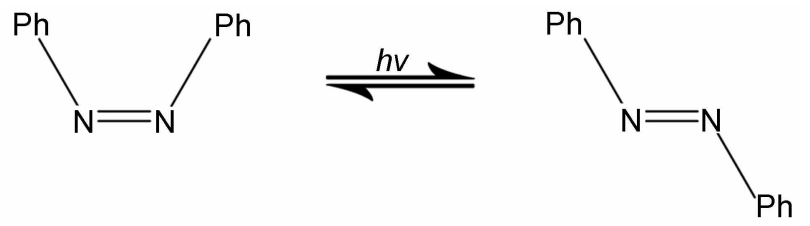

Figure 3. Cis- and trans-azobenzene (['h : phenyl).

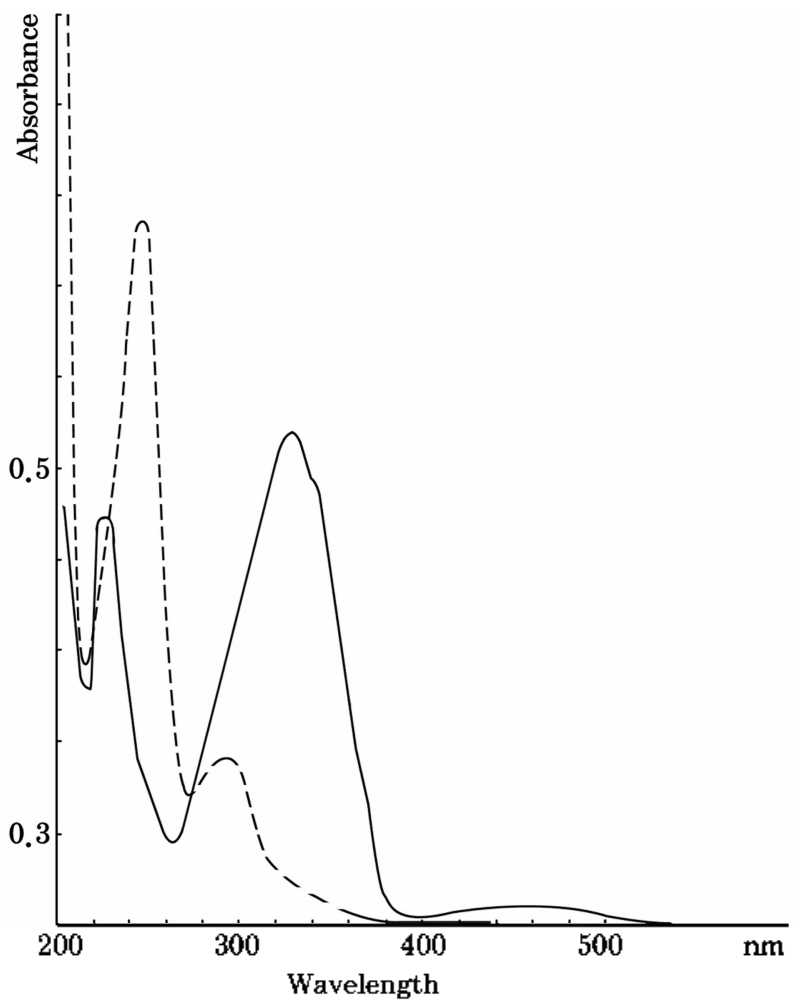

Figure 4. Absorption spectra of hydrazobenzene, broken curve, concentration $3.45 \times 10^{-2} \mathrm{M}$ and roms-azobenzene (solid curve, $\left.2.75 \times 10^{3} \mathrm{M}\right)$. Methanol, $25^{\circ} \mathrm{C}$.

experimental value of $41.8 \mathrm{~K} \cdot \mathrm{I} \cdot \mathrm{mol}^{-1}\left(10 \mathrm{Kcal} \cdot \mathrm{mol}^{-1}\right)$.

Absorption spectra of hydrazobenzene $\left(\mathrm{H}_{2} \mathrm{AB}\right)$ and trans- 
Table 4. Absorption maxima of hydrazobenzene, transazobenzene, and cis-azobenzene. Methanol, $25.0^{\circ} \mathrm{C}$

\begin{tabular}{|c|c|c|c|c|c|}
\hline \multicolumn{2}{|c|}{$\begin{array}{l}\text { Hydrazobenzene } \\
\qquad\left(\mathrm{I}_{2} \mathrm{Al} 3\right)\end{array}$} & \multicolumn{2}{|c|}{$\begin{array}{l}\text { Trans-azobenzene } \\
\quad(\text { trems-AI3) }\end{array}$} & \multicolumn{2}{|c|}{$\begin{array}{c}\text { Cis-azobenzene } \\
(c i s-\mathrm{AB})\end{array}$} \\
\hline$\overline{\bar{\lambda}}_{\text {ni:i:2 }}$ & $\varepsilon$ & $\lambda_{\text {tentax }}$ & $\varepsilon$ & $i_{\text {itrix }}$ & $c$ \\
\hline$(\mathrm{nm})(10$ & $\left(\mathrm{M}^{-1} \cdot \mathrm{cm}^{-1}\right)$ & $(\mathrm{nm})$ & $\left(10^{3} \mathrm{~W}^{-1}+\mathrm{cm}^{-1}\right)$ & $(\mathrm{nm})$ & $\left(10^{3} \mathrm{At}^{-1} \mathrm{~cm}^{-4}\right)$ \\
\hline 245 & 21.8 & 227 & 13.1 & 240 & $>8.61$ \\
\hline 289 & 5.23 & 315 & 16.1 & 298 & $>6.42$ \\
\hline$(315$ & 1.89) & $(437$ & $0.509)$ & 425 & $>1.36$ \\
\hline
\end{tabular}

Table 5. Further addition of hydrazobenzene to the reaction mixture

\begin{tabular}{cclc}
\hline Time (hour) & Absorbance & Time (hour) & Absorbance \\
\hline 0 & 0.132 & $0(49.8$ hrs.) & 0.620 \\
0.183 & 0.223 & 0.117 & 0.625 \\
0.417 & 0.290 & 0.217 & 0.626 \\
0.767 & 0.337 & 0.517 & 0.636 \\
1.58 & 0.339 & 1.48 & 0.670 \\
2.67 & 0.445 & 2.48 & 0.696 \\
4.17 & 0.478 & 3.57 & 0.719 \\
6.67 & 0.496 & 6.15 & 0.772 \\
18.5 & 0.509 & 22.4 & 0.809 \\
21.7 & 0.524 & 28.2 & 0.822 \\
24.2 & 0.523 & 35.1 & 0.825 \\
30.5 & 0.536 & & \\
49.8 & 0.538 & &
\end{tabular}

At time $=49.8$ hrs., a further addition of hydrazolenzene $(0.4606 \mathrm{~g}$ lo 50 $\mathrm{mL}$ solution) $\left(5.00 \times 10^{2} \mathrm{M}\right)$ to the reaction mixture. $O_{2}$ saturated mellanct, $25.0^{\circ} \mathrm{C}, \lambda \quad 437 \mathrm{~nm}, \mid \mathrm{Co}\left(3 \mathrm{MeOsal}\right.$ en) $\mid 5.24 \times 10^{-4} \mathrm{M}$, $\left[\mathrm{II}_{2} \mathrm{AH}\right]=1,01 \times 10^{-1} \mathrm{M}$

azobenzene $(A B)$ in methanol was recorded over the rage of $600-200 \mathrm{~nm}$, Figure 4. There are two bands observed at 245 non and $289 \mathrm{~nm}$. Fxtinction coeflicients for these and of cisazobenzene are given in Table 4 .

Some cis-ayobervene was produced from bons-azobenzene $\left(8.16 \times 10^{-3} \mathrm{M}\right)$ in methanol at $25.0^{\circ} \mathrm{C}$ by irradiating it for about three hours at $315 \mathrm{~mm}$ in the cell compartment of a Farrand spectrofluorometer with 20 nm slits. Each isomer of azobenzene has three bands. Two of the bands in transazobenzene was shifted to shorter wavelengths in the cis isomer. Table 4. The absorption spectrum of the isomers in methanol is similar to that of trons-azobenzene in ethanol. The extinction coefficients in Table 4 are exact as conversion to the cis isomer has not reached $100 \%$. During irradiation there was a large change in the absorbance of the bands at $315 \mathrm{~mm}$ and $437 \mathrm{~mm}$ in the first half hour, the rate of which decreased rapidly until after $21 / 2$ hours, after which there was no further change in the absorbance. If during the course of the oxidation of hydrazobenzene in methanol, cisazobenzene were formed as an intermediate, a band at 425 nIn (literature $433 \mathrm{~nm}$ in ethanol) ${ }^{26}$ should have been formed before the formation of the band at $437 \mathrm{~nm}$ due to trans-azobenzene.

The oxidation of hydrazobenzene $\left(1.01 \times 10^{-1} \mathrm{M}\right)$ catalysed by $\mathrm{Co}(3 \mathrm{MeOsalen})\left(5.24 \times 10^{-4} \mathrm{M}\right)$ produced transazobenzene as witnessed by a band at $437 \mathrm{~nm}$ in methanol at

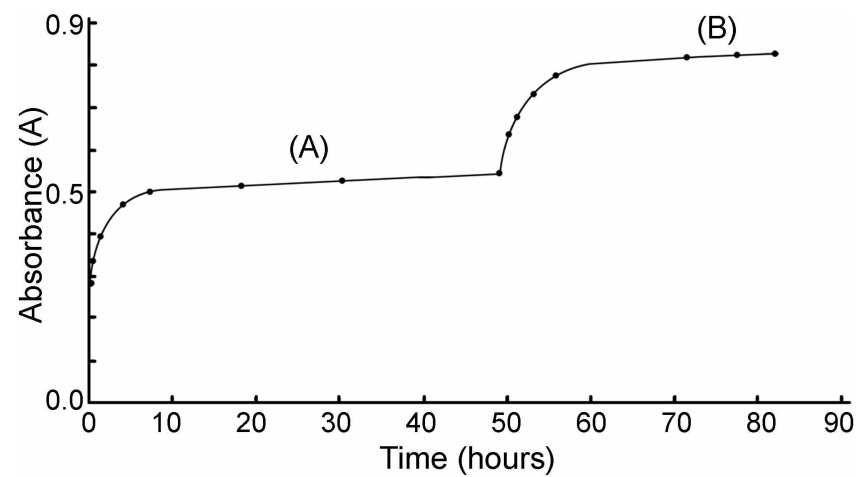

Figure 5. Plot of absorbance, $A$, against time, $O$ salurated methanol,

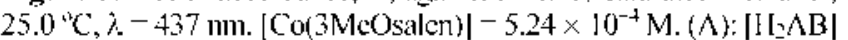
$-1.01 \times 10^{1} \mathrm{M}$ (initially); $(\mathrm{B}):\left[\mathrm{H}_{2} \mathrm{AB}\right]-0.500 \times 10^{1} \mathrm{M}(0.4606 \mathrm{~g}$ to $50 \mathrm{~mL}$ solution) (a further addtion at $(a .50 \mathrm{hrs}$ ).

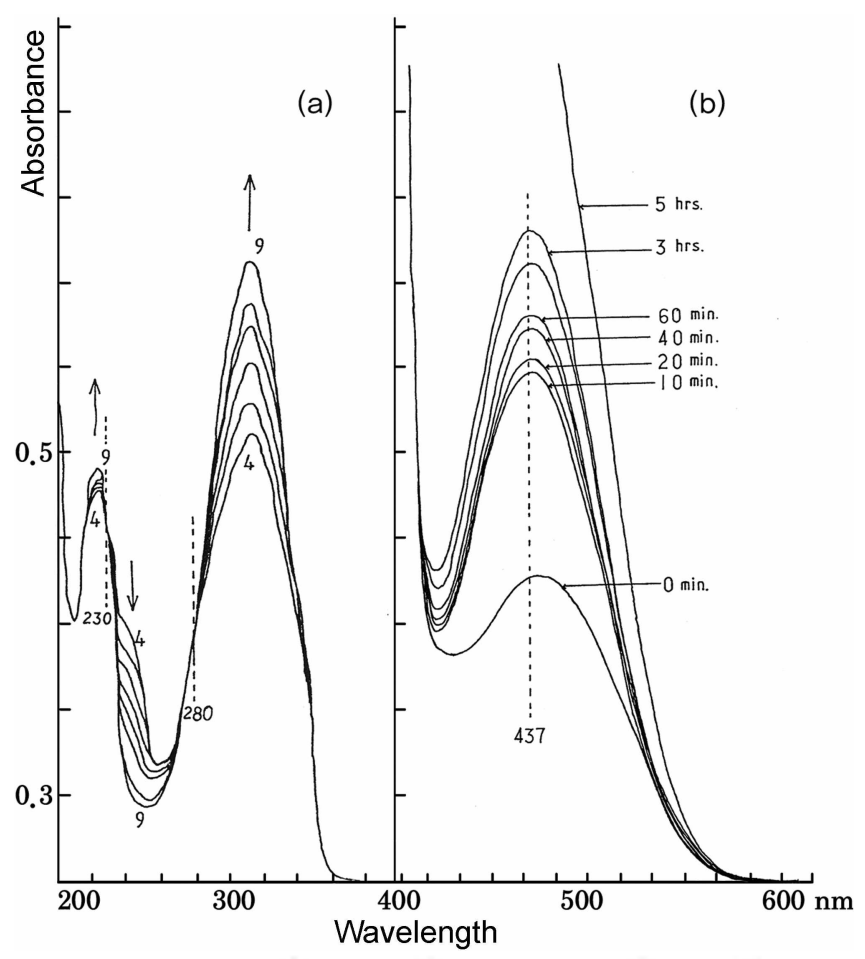

Figure 6. Changes in absorption spectra during reaction. $\mathrm{O}_{2}$ saturated in methanol, $1 \mathrm{~atm}, 25^{\circ} \mathrm{C}$. [Co(3MeOsalen $\left.)\right]=5.20 \times 10^{-1}$ M, $\left[\left.H_{2} \wedge B\right|_{6}-3.33 \times 10^{-5}\right.$ M. No. $4(20 \mathrm{~min}$.), No. $9(3 \mathrm{hrs}$.).

$25.0^{\circ} \mathrm{C}$. After most of the substrate was oxidised to azobenzene (in ca. 50 hours), a further addition of hydrazobenzene $\left(0.4606 \mathrm{~g} / 50 \mathrm{~mL}\right.$ methanol, $\left.5.00 \times 10^{-2} \mathrm{M}\right)$ into the reaction mixture was made. Table 5 . The absorbance at 437 $\mathrm{nm}$ again began to increase, and at a similar rate as before, showing that the catalyst remained active, Figure 5. The spectral changes during the reaction are indicated in Figure 5.

Figure 6 shows the time dependence of the changes in the absorption spectrum during the oxidation of hydrazobenzene $\left(3.33 \times 10^{-5} \mathrm{M}\right)$ with $\mathrm{Co}(3 \mathrm{MeO}$ salen $)\left(5.20 \times 10^{-6} \mathrm{M}\right)$ under oxygen at $25.0^{\circ} \mathrm{C}$. The band at $254 \mathrm{~nm}$ decreases with time in Figure $6 \mathrm{a}$, due to the oxidation of hydrazobenzene, while 


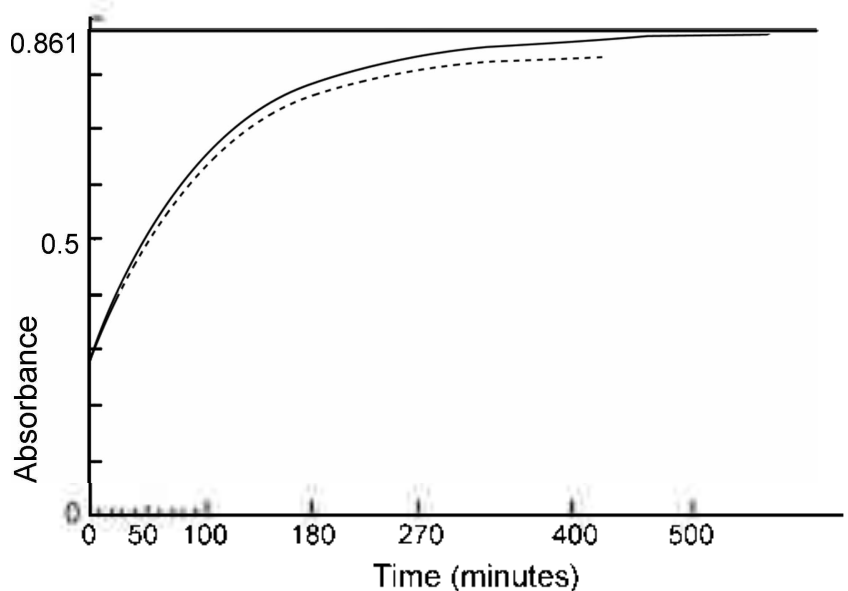

Figure 7. Plot of absorbance $\wedge$ (at $315 \mathrm{~mm}$ ) against lime, $O_{2}$ saturated in methanol, I atm, $25^{\circ} \mathrm{C}$. $[\mathrm{Co}(3 \mathrm{MeOsalen})]-5.67 \times 10^{-6}$ M. $\left[\mathrm{H}_{2} \mathrm{AB}\right]_{0}-3.26 \times 10^{.3} \mathrm{M}$. Solid curve, experi-mental; broken curve, calculated for pseudo-lirst order kinetics as described in the lext.

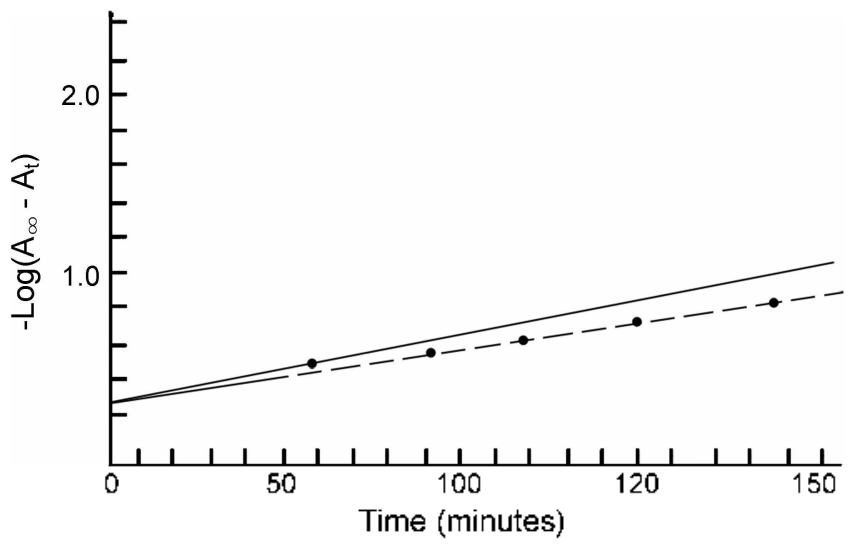

Figure 8. Plot of $-\log \left(A_{* x}-A_{t}\right)$ against time, $O_{2}$ saturated methanol, $25.0^{\circ} \mathrm{C}, \hat{\lambda}=315 \mathrm{~nm}$. $[\mathrm{Co}(3 \mathrm{MeOsalen})]=5.67 \times 10^{-6} \mathrm{M},\left[\mathrm{H}_{2} \mathrm{AB}\right]=$ $3.26 \times 10^{-5}$. M. $\Lambda_{r}=0.861$. Solid curve: observed value; Dotted line: Ist order kineties ealculated (rate constant $k-3.33 \times 10^{-4}$ $\sec { }^{1}$ ).

bands at $315 \mathrm{~nm}$ and $437 \mathrm{~nm}$ (see Figure 4), increase due to the formation of trans-azobenzene in Figures 6-a, b. During the oxidation reaction of hydrazobenzene, trans-azobenzene was exclusively produced, as indicated by the absorption spectra. The cis-isomer, which would have absorption maxima at $298 \mathrm{~mm}$ and $425 \mathrm{~nm}$, was not detected, Figure 6. There is an isosbestic point at $280 \mathrm{~mm}$, and in particular is no new band at $281 \mathrm{~nm}$. Hence the reaction product is transazobenzene, with negligible production of cis-isomer.

Kinetic measurements were made at $315 \mathrm{mn}$, Figure 7. A typical curve of absorbance A versus time $t$ is shown in Figure 7. Plots of $-\log (A-A)$ against time were found to be curved after approximately one half-life, 60 minutes, indicating deviation from pseudo first order kinetics. Figure 7 and 8 include a pseudo-first order curve calculated to fit the earlier part of the data. Comparison with th experimental data, Table 6 , shows that the reaction appears to go faster as reaction proceeds than would be expected for a simple first order reaction. This could be due to the oxidation of hydrazobenzene by the

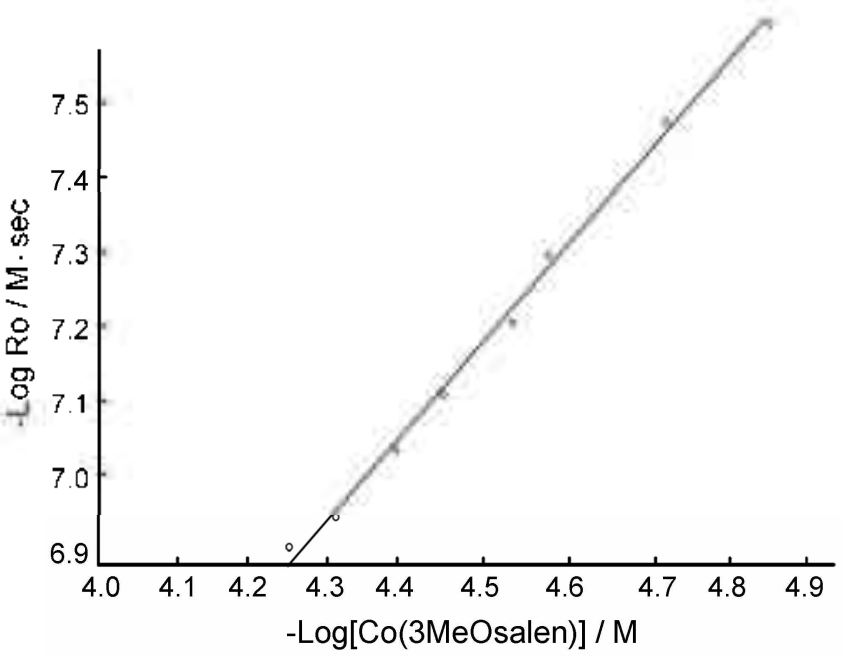

Figure 9. [']ot of $-\log \mathrm{R}_{6}$ against $\log [\mathrm{Co}(3 \mathrm{MeO} \text { salen })]_{1}$. $\mathrm{O}_{2}$ saturated methanol, 1 atm, $25^{\circ} \mathrm{C}, \hat{h}=315 \mathrm{~nm}$. The line is drawn with slope 1.00. $|\mathrm{Co}(3 \mathrm{MeOsalen})|-1.47 \times 10^{5} \mathrm{M}-5.57 \times 10^{5} \mathrm{M}$. $\left|\mathrm{H}_{2} \wedge \mathrm{B}\right|$, $-4.11 \times 10^{-1} \mathrm{M}$.

Table 6. $\log \left(\Lambda \ldots-\Lambda_{1}\right)$ values compared with first order kinetics

\begin{tabular}{rcccc}
\hline Time/min & $\begin{array}{c}\text { Absorbance } \\
\text { (observed) }\end{array}$ & $\begin{array}{c}-\log \\
\left(A_{x}-A 1\right)\end{array}$ & $\begin{array}{c}\text { Absorbance } \\
\text { (Calculated) }\end{array}$ & $\begin{array}{c}\text { - log } \\
\text { (1st order) }\end{array}$ \\
\hline 0 & 0.306 & 0.256 & 0.306 & 0.256 \\
10 & 0.349 & 0.291 & 0.349 & 0.291 \\
20 & 0.395 & 0.332 & 0.395 & 0.332 \\
30 & 0.438 & 0.374 & 0.438 & 0.374 \\
60 & 0.549 & 0.506 & 0.537 & 0.489 \\
90 & 0.633 & 0.642 & 0.615 & 0.609 \\
120 & 0.696 & 0.783 & 0.675 & 0.730 \\
150 & 0.744 & 0.932 & 0.717 & 0.842 \\
180 & 0.776 & 1.07 & 0.752 & 0.963 \\
2106 & 0.861 & & & \\
\hline
\end{tabular}

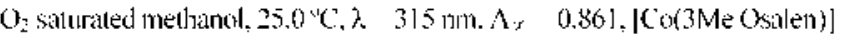
$=5.67 \times 10^{-t} \mathrm{M},[\mathrm{I} \cdot \mathrm{NB}]=3.26 \times 10^{-5} \mathrm{M}$.

hydrogen peroxide produced. ${ }^{18}$ We have demonstrated that hydrogen peroxide $\left(8.29 \times 10^{-3} \mathrm{M}\right)$ reacted with hydrazobenzene $\left(3.88 \times 10^{-4} \mathrm{M}\right)$ employing the initial rate method, Table 7. The maximum possible rate for the oxidation of hydrazobenzene by hydrogen peroxide in the catalysed reaction would be when half the hydrazobenzene had been oxidised, equation (3). Assuming that the initial rate $\mathrm{R}_{\mathrm{o}}$ is linear (first order) in hydrazobenzene and hydrogen peroxide concentration, the initial rate at $\left[\mathrm{H}_{2} \mathrm{AB}\right]=\left[\mathrm{H}_{2} \mathrm{O}_{2}\right]=$ $1.63 \times 10^{-5} \mathrm{M}$ will be $9.33 \times 10^{-14} \mathrm{M} \mathrm{sec}^{-1}$ which is given by

$$
\begin{aligned}
\mathrm{R}_{\mathrm{e}}=\frac{1.13 \times 10^{\circ} \mathrm{M} \mathrm{sec}^{1}}{8.29 \times 10^{\circ} \mathrm{M}\left(\mathrm{H}_{2} \mathrm{O}_{2}\right)} & \times 1.63 \times 10^{-5} \mathrm{M}\left(\mathrm{I}_{2} \mathrm{O}_{2}\right) \\
& \times \frac{1.63 \times 10^{-5} \mathrm{M}\left(\mathrm{I}_{2} \mathrm{AB}\right)}{3.88 \times 10^{-4} \mathrm{M}\left(\mathrm{I}_{2} \mathrm{AB}\right)}
\end{aligned}
$$

which is obtained, Table 7 . This is much less than the initial rate observed $\left(2.74 \times 10^{-9} \mathrm{M} \cdot \mathrm{sec}^{-1}\right)$ in the catalysed reaction, Table 7.

To avoid this complication, initial rates $R_{b}$, equation (4) 
Table 7. Fiflect of varing $\mathrm{H}_{2} \mathrm{O}_{2}$ concentration on the oxidation of hydravoben\%ene in $\mathrm{O}$. saturated methanol at $25.0^{\circ} \mathrm{C}$

\begin{tabular}{ccc}
\hline$\left[\mathrm{H}_{2} \mathrm{O}_{2}\right] / 10^{-9} \mathrm{M}$ & $(\mathrm{dA} / \mathrm{d})_{\alpha} / 10^{-4} \mathrm{sec}^{-1}$ & $\mathrm{R}_{4} / 10^{-4} \mathrm{M} \mathrm{sec}^{-1}$ \\
\hline 0 & 0.229 & $1.6]$ \\
0.829 & 0.389 & 2.74 \\
4.15 & 1.04 & 7.32 \\
5.80 & 1.44 & 10.1 \\
8.29 & 2.06 & 14.5
\end{tabular}

$\lambda=315 \mathrm{~nm}\left(\varepsilon[\mathrm{I} I \mathrm{~L})=1.89 \times 10^{3} \mathrm{M}^{-1} \mathrm{~cm}^{-1}, \varepsilon(\mathrm{AB})=1.61 \times 10^{4}\right.$ $\mathrm{M}^{-1} \mathrm{~cm}^{-},\left[|\mathrm{I} . \Delta \mathrm{B}| \mathrm{i}, 3.88 \times 10^{-1} \mathrm{M}, \Delta \varepsilon^{-1} \quad 7.04 \times 10^{-5} \mathrm{M} \cdot \mathrm{cm}, \mathrm{R}, \Delta \varepsilon^{-1}\right.$ $(\mathrm{d} / \mathrm{d} / \mathrm{d})$

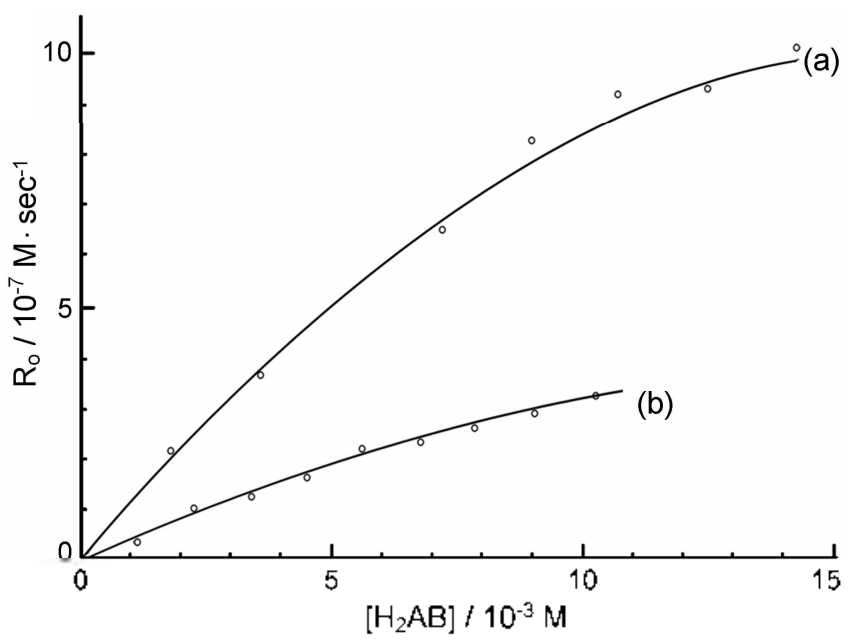

Figure 10. Plots of initial rate $R_{\mathrm{c}}$ against ||$I_{3} A B \mid$. Curve (a) 0 , saturated, Curve (b) air saturated, methanol., 1 atm, $25^{\prime \prime} \mathrm{C}, \lambda-315$ $\mathrm{nm}$ and $437 \mathrm{~nm}$. [Co $]_{1}=7.43 \times 10^{-6} \mathrm{M}$.

were calculated from slopes of langents at $\mathrm{\iota}=0$ :

$$
\mathrm{R}_{4}=\mathrm{l}^{-1} \cdot(\Delta \varepsilon)^{-1} \cdot(\mathrm{d} \Lambda / \mathrm{dt})_{0}
$$

which is derived from $\mathrm{A}=\mathrm{ecl}$ where $\mathrm{l}$ is the path length and $\Delta \varepsilon^{-1}=7.04 \times 10^{-5} \mathrm{M}^{-1} \mathrm{~cm}$ obtained from intercept with log $\mathrm{R}_{\mathrm{o}}$ against $\log (\mathrm{d} \mathrm{A} / \mathrm{dt})_{4}$.

The log of the initial rate is plotted against the log of the Co(3MeOsalen) concentration, Figure 9. The slope of this

Table 8. Effect of varing [Co(3MeOsalen)] concentration on the oxidation of hydrazobenzene in $\mathrm{O}_{2}$ saturated methanol at $25.0^{\circ} \mathrm{C}$

\begin{tabular}{|c|c|c|c|c|}
\hline $\begin{array}{c}{\left[\mathrm{Co}_{0}\left(3 \mathrm{Me}()_{\mathrm{salen}}\right)\right]} \\
110^{-3} \mathrm{M}\end{array}$ & $\begin{array}{l}(\mathrm{d} N / \mathrm{dt})_{k t} \\
10^{-4} \mathrm{sec}^{-1}\end{array}$ & $\begin{array}{l}\mathrm{R}_{\mathrm{u}} / / 0^{-8} \\
\mathrm{M} \cdot \mathrm{sec}^{-1}\end{array}$ & $\begin{array}{l}-\log \mathrm{R}_{0} / \\
\mathrm{M} \cdot \mathrm{sec}^{-1}\end{array}$ & $\begin{array}{c}-\log \left[\mathrm{Cos}_{0}(3 \mathrm{MaO})\right. \\
\text { salen)]/M }\end{array}$ \\
\hline 0 & 0.305 & 0.215 & 8.67 & - \\
\hline 1.47 & 4.00 & 2.82 & 7.55 & 4.83 \\
\hline 2.05 & 5.53 & 3.89 & 7.41 & 4.69 \\
\hline 2.64 & 7.44 & 5.24 & 7.28 & 4.58 \\
\hline 3.22 & 9.50 & 6.69 & 7.17 & 4.49 \\
\hline 3.81 & 11.5 & 8.09 & 7.09 & 4.42 \\
\hline 4.39 & 13.5 & 9.50 & 7.02 & 4.36 \\
\hline 4.98 & 15.7 & 11.1 & 6.95 & 4.30 \\
\hline 5.57 & 17.2 & 12.1 & 6.92 & 4.25 \\
\hline
\end{tabular}

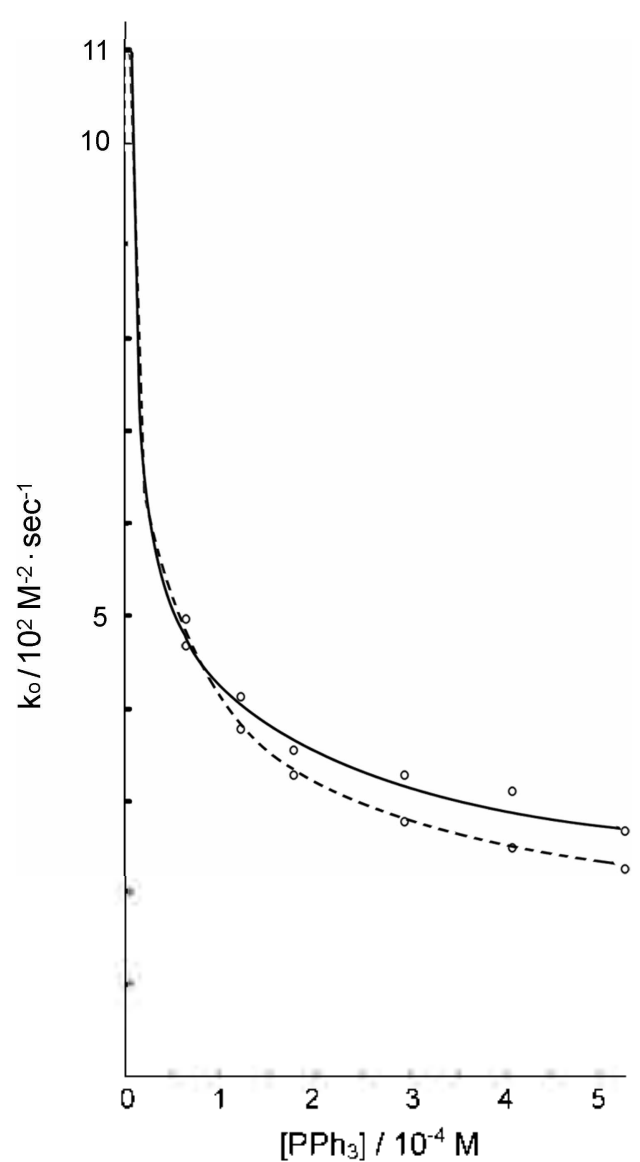

Figure 11. Plots of $\mathrm{k}$ againsl $\left[\mathrm{PP} \mathrm{h}_{2}\right]$. O $\mathrm{O}_{2}$ saturated methanol, 25.0 ${ }^{\circ} \mathrm{C}, \lambda-315 \mathrm{~mm}$. [Co(3McOsalen) $]-4.78 \times 10^{-5} \mathrm{M},\left|\mathrm{J}_{2} \mathrm{AB}\right|-1.95$ $\times 10^{+} \mathrm{M}$, Solid curve: experimental value; dotted curve: theoretical value.

plot is 1.00 . Table 8 , which shows that the reaction is first order in calalyst, equation (5). The dependence of rate on total cobalt concentration $\left[\mathrm{C}_{0}\right]_{\mathrm{T}}$ is linear, over the range

$$
\mathrm{R}_{0} \propto[\mathrm{Co}(\mathrm{II})\rceil
$$

$\left[\mathrm{Co}_{\mathrm{T}}\right]_{\mathrm{T}}=(1.5-5.6) \times 10^{-5} \mathrm{M}$, Figure 9 .

The hydrazobenzene dependence is non-linear, suggesting an equilibrium saturation effect, Figure 10 . The oxygen dependence, based on measurements at two concentrations, is also non-linear as discussed below. The initial rate of the oxidation reaction of hydrazobenzene in an $\mathrm{O}_{2}$ saturated solution is faster than that in air by about three times, for example in the region $\left[\mathrm{H}_{2} \mathrm{AB}\right]=10 \times 10^{-3} \mathrm{M}$, Table 2 and 3 . The data, Figure 10 , show that the initial reaction rates are linear in hydrazobenzene concentration at low concentrations, especially for the reaction in air, as expected for a first order reaction. However, as the hydrazobenzene concentration increases the reaction order in substrate appears to decrease, until above $10^{-2} \mathrm{M}$ hydrazobenzene in oxygen the reaction becomes independent of substrate concentration. This is similar to the behaviour observed in enzyme systems where it would indicate saturation of the catalyst with substrate as the Michaelis-Menten equation.

The reaction was followed with $\mathrm{Co}(3 \mathrm{MeO}$ salen $)(7.43 \times$ 
$\left.10^{-5} \mathrm{M}\right)$ and the appropriate ligands: triphenylphosphine $\left(1.91 \times 10^{-2} \mathrm{M}\right)$, ethylisonicotinate $\left(3.57 \times 10^{-2} \mathrm{M}\right)$. Table 9 . As the ligand triphenylphosphine $\left(1.91 \times 10^{-2} \mathrm{M}\right)$ was added to the reaction mixture, Table 10 , the initial rate was decreased. It was also observed that the colour of the catalytic system changed from red to green. The destruction of catalytic system $\mathrm{Co}(3 \mathrm{MeOsalen})\left(\mathrm{O}_{2}\right)$ could be due to the catalyst becoming coordinated with triphenylphosphine in both $Z$ axis sites of the catalyst. There was a little change in rate wher ethylisonicotinate $\left(3.57 \times 10^{-2} \mathrm{M}\right)$ was added to the reaction mixture. Table 9. However, when a strong $\sigma$ donor ligand, pyridine $\left(2.00 \times 10^{-3} \mathrm{M}\right)$, was added to the reaction mixture of hydrazobenzene, the reaction rate was increased. These ligands could affect dioxygen binding to

Table 9. Ligand effect on the oxidation of hydrazobenzene in $\mathrm{O}_{2}$ saturated methanol at $25.0^{\circ} \mathrm{C}$

\begin{tabular}{|c|c|c|c|c|c|c|}
\hline \multirow{2}{*}[\mathrm{H}_{2}\mathrm{AB}]{$/ 10^{-3} \mathrm{M}$} & \multicolumn{3}{|c|}{$(\mathrm{dA} / \mathrm{dt})_{0} / 10^{-3} \mathrm{sec}^{-1}$} & \multicolumn{3}{|c|}{$\mathrm{R}_{\mathrm{g}} / 10^{-7} \mathrm{M} \sec ^{-1}$} \\
\hline & $\mathrm{MeOH}$ & EIN & $\mathrm{PPh}_{3}$ & $\mathrm{MeOH}$ & EIN & $\mathrm{PPh}_{\mathrm{s}}$ \\
\hline 1.70 & 4.50 & 4.50 & 1.20 & 3.17 & 3.17 & 0.845 \\
\hline 3.70 & 7.40 & 7.40 & 2.50 & 5.21 & 5.21 & 1.76 \\
\hline 7.30 & 13.2 & 12.7 & 3.40 & 9.29 & 8.94 & 2.39 \\
\hline 10.0 & 18.6 & 16.8 & 3.70 & 13.1 & 11.8 & 2.60 \\
\hline 14.6 & 20.8 & 21.5 & 4.10 & 14.6 & 15.1 & 2.89 \\
\hline
\end{tabular}

$\lambda=315 \mathrm{~mm}\left(\varepsilon \mathrm{I}[\mathrm{AB})=1.89 \times 10^{3} \mathrm{M}^{-1} \mathrm{~cm}^{-1}\right),(\varepsilon \mathrm{AB})=1.61 \times 10^{4} \mathrm{M}^{-1}$ $\left.\mathrm{cm}^{-}\right) \lambda=437 \mathrm{~mm}\left(\varepsilon=5.09 \times 10^{2} \mathrm{M}^{-1} \mathrm{~cm}^{-1}\right),[\mathrm{Cot} 3 \mathrm{MeO}$ salen $)=7.43$ $\times 10^{-4} \mathrm{M}$. Ethy lisonicotinate $=[\mathrm{EIN}]=3.57 \times 10^{-3} \mathrm{M} . \mathrm{R}_{0}=\Delta \varepsilon^{-1} \mathrm{si} \leq \mathrm{d \textrm {dA }}$ $\mathrm{d})_{0,} \Delta \varepsilon^{-1}: \leq=7.43 \times 10^{-5} \mathrm{M} \cdot \mathrm{cm}$. Tripheny lphosphine $=\left[\mathrm{PPh}_{3}\right]=1.91 \times$ $10^{-3} \mathrm{M}$. the catalytic system $\mathrm{Co}(3 \mathrm{Me} \mathrm{Osalen})\left(\mathrm{O}_{2}\right)$ as triphemylphosphine is usually considered to have not only $\sigma$-donor but also $\pi$-acceptor properties, ${ }^{27}$ ethylisonicotinate is a $\sigma$ donor, ${ }^{1 / 3}$ and pyridine a strong $\sigma$-donor ligand.

Triphenylphospline is an interesting ligand as it decreases the rate of the oxidation of hydrazobenzene in methanol. The initial rates, $\mathrm{R}_{0}$ of the oxidation of hydrazobenzene with the ligand triphenylphosphine( $\mathrm{PPh}_{\mathfrak{y}}$ ) were measured, Table 10 . As the triphenylphosphine concentrations increased, the initial rates were found to decrease. When the initial rates were plotted against the triphenylphosphine concentration, a curve was formed and theoretical values of the initial rates as a dotted curve, Figure 11. The theoretical values of the rates, Table 11, were calculated from equation (6):

$$
\text { Rate }=k=\frac{k_{1}+k_{2} K_{1}[\mathrm{P}]}{1+K_{1}[\mathrm{P}]+K_{1} K_{1}[\mathrm{P}]^{2}}
$$

$$
\text { where } \begin{aligned}
& k=\left(\mathrm{R}_{\mathrm{i}}-k_{0}[\mathrm{~S}]\left[\mathrm{O}_{-}\right]\right) /[\mathrm{S}]\left[\mathrm{O}_{-}\right]\left[\mathrm{C}_{\mathrm{T}}\right. \\
& \mathrm{R}_{\mathrm{j}}=\text { initial rate } \\
& k_{0}=\text { rate constant for autoxiation } \\
& {[\mathrm{C}]_{\mathrm{T}}=\text { total concentration of the catalyst } \mathrm{Co}(3 \mathrm{Me}} \\
& \text { Osalen) } \\
& {[\mathrm{S}]=\left[\mathrm{H}_{2} \mathrm{AB}\right]} \\
& {[\mathrm{P}]=\left[\mathrm{PP} h_{\hat{j}}\right]} \\
& k_{1}=\text { rate constant for the oxidation without } \mathrm{PPh}_{\hat{\jmath}} \\
& k_{2}=\text { rate constant for the oxidation with } \mathrm{PPh}_{3} \\
& K_{3}=\text { equilibrium constant in equation }(7) \\
& K_{2}=\text { equilibrium constant in equation }(8)
\end{aligned}
$$

\begin{tabular}{|c|c|c|c|c|c|c|c|}
\hline $\begin{array}{c}{\left[\mathrm{PPh}_{3}\right] / 10^{-4}} \\
\mathrm{M}\end{array}$ & $\begin{array}{c}\text { (dA/ dt })_{6} / 10^{-4} \\
\sec ^{-1}\end{array}$ & $\begin{array}{l}\mathrm{R}_{\mathrm{l}} / 10^{-8} \\
\mathrm{M} \cdot \mathrm{sec}^{-1}\end{array}$ & $\begin{array}{l}\mathrm{R} ; / 10^{-8} \\
\mathrm{M} \cdot \mathrm{sec}^{-1}\end{array}$ & $\begin{array}{c}k: 10^{3} \\
\mathrm{M}^{-2} \cdot \mathrm{Sec}^{-1}\end{array}$ & $\begin{array}{l}\left(k-k_{1}\right) 10^{2} \\
\mathrm{M}^{-2} \cdot \sec ^{-1}\end{array}$ & $\begin{array}{c}{[P]:\left(k-k_{l}\right) / 10^{-7}} \\
M^{3} \cdot \sec \end{array}$ & $\begin{array}{l}\mathrm{k}^{-1} / 10^{-3} \\
\mathrm{M}^{2} \cdot \sec \end{array}$ \\
\hline 0 & 14.2 & 9.99 & 9.99 & 11.0 & 0 & - & 0.909 \\
\hline 0.529 & 6.25 & 4.40 & 4.32 & 4.80 & -6.20 & 0.853 & 2.19 \\
\hline 1.09 & 5.54 & 3.90 & 3.82 & 4.25 & -6.75 & 1.61 & 2.36 \\
\hline 1.60 & 4.83 & 3.40 & 3.32 & 3.69 & -7.31 & 2.19 & 2.71 \\
\hline 2.70 & 4.47 & 3.15 & 3.07 & 3.41 & -7.59 & 3.56 & 2.93 \\
\hline 3.77 & 4.26 & 3.00 & 2.92 & 3.24 & -7.76 & 4.86 & 3.09 \\
\hline 4.88 & 3.76 & 2.65 & 2.57 & 2.86 & -8.14 & 5.99 & 3.49 \\
\hline
\end{tabular}

Table 10. Effect of varing triphenylphosphine concentration $\left[\mathrm{PPh}_{3}\right]$ on the oxidation of hydrazobenzene $\left[\mathrm{H}_{2} \mathrm{AB}\right]$ in $\mathrm{O}_{2}$ saturated methanol at $25.0^{\circ} \mathrm{C}$

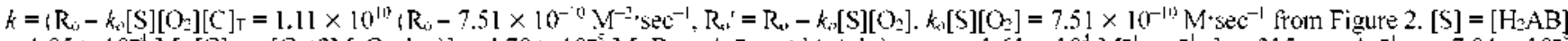

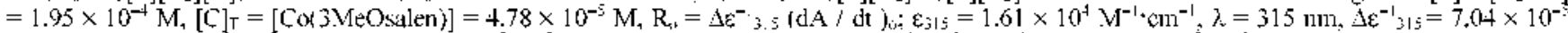
$\mathrm{Mcm}, k_{1}=1.10 \times 10^{2} \mathrm{M}^{-1} \cdot \mathrm{sec}^{-}, k_{2}=2.69 \times 10^{2} \mathrm{M}^{-2} \cdot \mathrm{sec}^{-},[\mathrm{P}]=\mathrm{PPh}_{31}, K_{1}=4.56 \times 10^{-1} \mathrm{dm}^{3} \cdot \mathrm{mol}^{-1}, K_{3}=5.39 \times 10^{\frac{3}{2}} \mathrm{dm}^{3} \cdot \mathrm{mol}^{-1}$.

Table 11. Theoretical values of the rates calculated from equation (6) using the values of $k_{1}, k_{2}, K_{1}$, and $K_{2}$

\begin{tabular}{ccccccc}
\hline$\left[\mathrm{PPh}_{3}\right] / 10^{-4} \mathrm{M}$ & {$\left[\mathrm{P}^{2} / 10^{-8}\right.$} & $1+\mathrm{K}_{1}[\mathrm{P}]$ & $\mathrm{K}_{1} \mathrm{~K}_{2}[\mathrm{P}]^{2}$ & $\left(\mathrm{k}_{1}+\mathrm{k}_{2} \mathrm{~K}_{1}[\mathrm{P}]\right) / 10^{3}$ & $\mathrm{l}-\mathrm{K}_{1}[\mathrm{P}]-\mathrm{K}_{1} \mathrm{~K}_{2}[\mathrm{P}]^{2} \quad k / 10^{3}$ \\
\hline 0 & 0 & 1 & 0 & 1.10 & 1 & 11.0 \\
0.529 & 0.279 & 3.41 & 0.0686 & 1.76 & 3.48 & 5.06 \\
1.09 & 1.19 & 5.97 & 0.293 & 2.45 & 6.26 & 3.91 \\
1.60 & 2.56 & 8.29 & 0.629 & 3.08 & 1.92 & 3.45 \\
2.70 & 7.29 & 13.3 & 1.79 & 4.43 & 21.7 & 2.93 \\
3.77 & 14.2 & 18.2 & 3.49 & 5.75 & 29.2 & 2.65 \\
4.88 & 23.8 & 23.3 & 5.85 & 7.11 & 2.43 \\
\hline
\end{tabular}

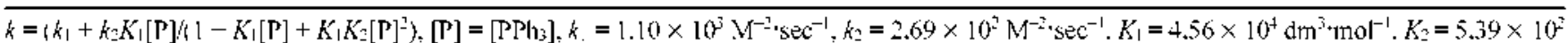
$\mathrm{dm}^{3} \cdot \mathrm{mol}^{-1}$. 
Table 12. Rate and Fquilibrium Constants at $25^{~ " C}$.

\begin{tabular}{|c|c|}
\hline $\begin{array}{l}\mathrm{K}_{\mathrm{N}} \\
\mathrm{k}_{\mathrm{c}}\end{array}$ & $\begin{array}{c}0+10 \mathrm{M}^{-1} \\
(2.96+0.2) \times 10^{-1} \mathrm{sec}^{-1}\end{array}$ \\
\hline$\frac{\mathrm{l}+\mathrm{K}_{\mathrm{u}}\left[\mathrm{O}_{2}\right]}{\mathrm{k}_{\mathrm{c}} \mathrm{k}\left[\mathrm{O}_{2}\right]}$ & $\begin{array}{l}(2.05 \pm 0.04) \times 10^{-1} \mathrm{M} \cdot \sec \left(\left[\mathrm{O}_{2}\right]-1.96 \times 10^{-3} \mathrm{M}\right)_{6} \\
(5.75 \pm 0.2) 10^{-3} \mathrm{M} \cdot \mathrm{sec}\left(\left[\mathrm{O}_{2}\right]-9.63 \times 10^{-3} \mathrm{M}\right)_{h}\end{array}$ \\
\hline $\mathrm{K}_{\mathrm{o}}$ & $(5.42+0.1) \times 10^{1} \mathrm{M}^{-1}$ \\
\hline $\mathrm{K}$ & $(9.33+0.5) \times 10^{3} \mathrm{M}^{-2}$ \\
\hline$K_{N}^{\prime}$ & $(1.72+0.09) \times 10^{-2} \mathrm{M}^{-1}$ \\
\hline
\end{tabular}

$\mathrm{K}=\mathrm{K}_{1} \mathrm{~K}_{\mathrm{x}}$. "Shechan, W. F. "Plyysical Chemistry", 2nd. ed. Allyn and Bacon (1970), pp. 285. "Gjaldhek .1. C., Acta Chemica Scandinavica, 6, 623 (1952), ; More (1972).

$$
\begin{array}{cl}
\mathrm{C}-\mathrm{P} & \stackrel{K_{1}}{\Leftrightarrow} \mathrm{C} \cdot \mathrm{P} \\
\mathrm{C} \cdot \mathrm{P} \text { । } \mathrm{P} & \stackrel{K_{2}}{\Leftrightarrow} \mathrm{C} \cdot \mathrm{P}_{2}
\end{array}
$$

where $C$ and $P$ are catalyst and triphenylphosphine. The equation (6) was derived from rate law.

The constants $k_{2}, K_{1}$, and $K_{2}$ were determined by reciprocal plots from equation (6), and $k_{1}$ is known to be $1.10 \times 10^{3} \mathrm{M}^{-2} \sec ^{-1}$ when $[\mathrm{P}]=0$, Table 10 .

When $\left[{ }^{3}\right]$ is small, equation (6) reduces to equation (9) as $K_{1}[\mathrm{P}] \geqslant K_{1} K_{2}\left[\mathrm{P}^{2}\right]^{-}$

$$
k \cong \frac{k_{1}+k_{2} K_{1} \mathrm{P}}{1+K_{\mathrm{l}} \mathrm{P}} \text {, where } \mathrm{P}=[\mathrm{P}]
$$

Subtracting $\mathrm{k}_{\mathrm{l}}$ from both sides,

$$
\begin{gathered}
\frac{k_{1}-k_{1}}{\mathrm{P}}-\frac{k_{2} k_{1}-k_{1} K_{1}}{\mathrm{I}+K_{1} \mathrm{P}} \\
\frac{\mathrm{P}}{k_{1}-k_{1}}=\frac{1}{K_{1}\left(k_{2}-k_{1}\right)}+\frac{\mathrm{P}}{k_{2}-k_{1}}
\end{gathered}
$$

$\mathrm{P} /\left(k-k_{1}\right)$ is plotted against $\mathrm{P}$ from equation (9), Figure 12 , $K_{1}$ and $k_{2}$ were oblained graphically, Table 11 . When $[\mathrm{P}]$ is large, equation (6) reduces to equation (10) as $k_{1}$ \& $k_{2} K_{1}[\mathrm{P}]$ and $1 \ll K_{\mid}[\mathrm{P}]$

$$
\begin{gathered}
k \equiv \frac{k_{2} K_{1} \mathrm{P}}{K_{1} \mathrm{P}+K_{1} K_{2} \mathrm{P}^{2}}=\frac{k_{2}}{1+K_{2} \mathrm{P}} \\
\frac{1}{k}=\frac{1}{k_{2}}+\frac{K_{2} \mathrm{P}}{k_{2}}
\end{gathered}
$$

$1 / k$ is plotted against $P$ from equation (10), Figure 13 , and $K_{2}$ was determined graphically, Table 11 . As the theoretical values of the initial rates agreed fairly well with experimental observations, Figure 11 , it is suggested that the catalyst $\mathrm{Co}(3 \mathrm{MeOsalen})$ was associated with triphenylphosphine which would be a poorer $\sigma$ donor ligand compared with methanol molecule and the reaction rate therefore decreased. The large $K_{1}$ value $\left(K_{1}=4.56 \times 10^{4} \mathrm{dm}^{3} \cdot \mathrm{mol}^{-1}\right)$ means that the equilibrium to $\operatorname{Co}(3 \mathrm{MeO}$ salen $)\left(\mathrm{PPh}_{3}\right)$ was soon achieved and was ready to associated with triphenylphosphine and became $\mathrm{Co}(3 \mathrm{MeOsalen})\left(\mathrm{PPh}_{3}\right)_{2}$ which is catalytically inactive and the rates were then expected to decrease quickly.

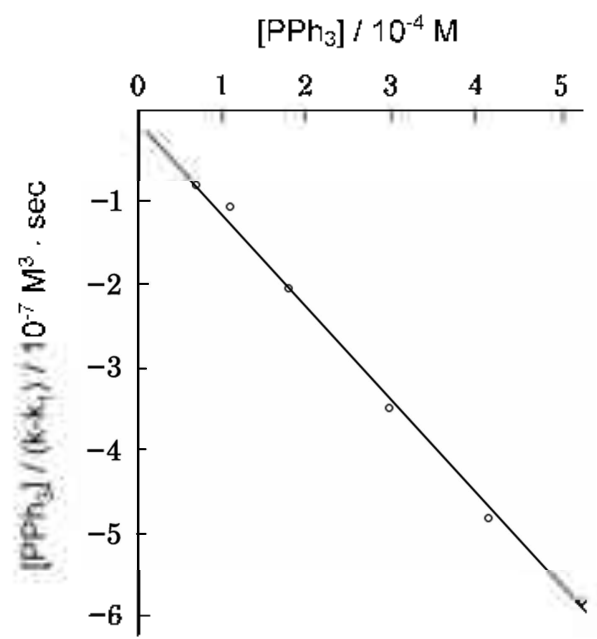

Figure 12. Plot of $\left[\mathrm{PPh}_{7}\right] /\left(k-k_{1}\right)$ against $\left[\mathrm{PPh}_{1}\right]$, when $[\mathrm{PPh}]$ is small. On saturatod methanol, $25.0^{\circ} \mathrm{C}, \hat{\lambda}-315 \mathrm{~mm},|\mathrm{Co}(3 \mathrm{MeOsalen})|^{-}$ $4.78 \times 10^{5} \mathrm{M}_{1}\left[\mathrm{H}_{2} \mathrm{AB}\right]-1.95 \times 10^{+} \mathrm{M}, k_{1}-1.10 \times 10^{2} \mathrm{M}^{2} \cdot \mathrm{sec}$, $k_{2}=2.69 \times 10^{7} \mathrm{M}^{-2} \cdot \mathrm{sec}^{-1}, K_{1}=4.56 \times 10^{7} \mathrm{M}^{-1} \mathrm{dm} \cdot \mathrm{mol} \mathrm{m}^{-1}$.

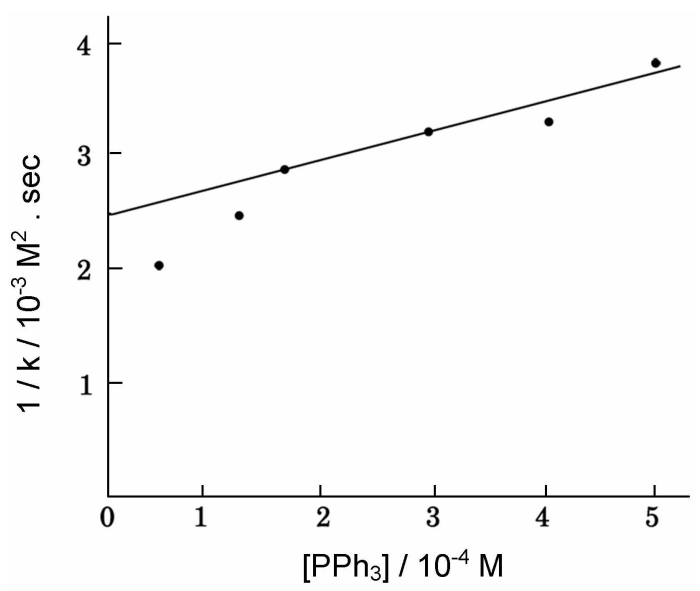

Figure 13. Plot of $1 / k$ against $\left[\mathrm{PPh}_{3}\right]$, when $\left[\mathrm{PPh}_{2}\right]$ is large. $\mathrm{O}_{2}$ saturated methanol, $25.0^{\prime \prime} \mathrm{C}, \hat{\lambda}=315 \mathrm{~nm},[\mathrm{Co}(\mathrm{SMeOsalen})]=4.78$ $\times 10^{-5} \mathrm{M},\left[\mathrm{II}_{2} \mathrm{Al}\right]=1.95 \times 10^{-4} \mathrm{M}, K_{2}=5.39 \times 10^{2} \mathrm{dm}^{3} \cdot \mathrm{mol}^{-1}$.

\section{Discussion}

The data suggest the formation of a ternary complex CoL $\cdot \mathrm{H}_{2} \mathrm{AB} \cdot \mathrm{O}_{2}$ (where $\mathrm{L}=3 \mathrm{MeOsalen}$ ), Scheme 1. ${ }^{2 *}$ For completeness, we introduce stepwise equilibria for the formation of this complex, via the two binary complexes $\mathrm{CoL} \cdot \mathrm{H}_{2} \mathrm{AB}$ and $\mathrm{CoL} \cdot \mathrm{O}_{2}$ :

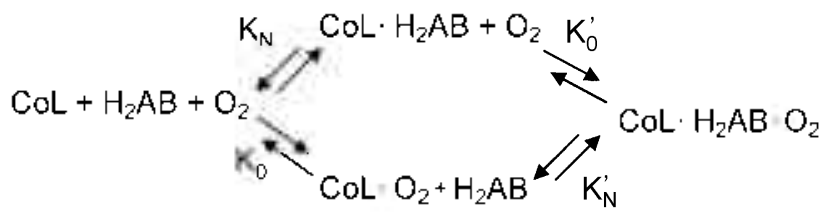

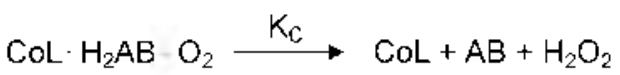

Scheme 1 
Under the experimental conditions

$$
\left[\mathrm{O}_{2}\right]>\left[\mathrm{H} \mathrm{I}_{2} \mathrm{AB}\right]>[\mathrm{CoL}]
$$

the rate of reaction is derived as follows: The rate of formation of the product, arobenzene (AB), is given by equation (11).

$$
\frac{\mathrm{d}[\mathrm{AB}]}{\mathrm{dt}}=K_{c}\left[\mathrm{C} \leftrightarrow \mathrm{L} \cdot \mathrm{H}_{2} \mathrm{AB} \cdot \mathrm{O}_{2}\right]
$$

The equiliriun constants $K_{t,} K_{i,}$ and $K_{*}^{\prime}$ are defined in equations (12)-(14).

$$
\begin{aligned}
& K_{0}=\frac{\left[\mathrm{CoL} \cdot \mathrm{O}_{2}\right]\left[\mathrm{H}_{2} \mathrm{AB}\right]}{[\mathrm{CoL}]\left[\mathrm{H}_{2} \mathrm{AB}\right]\left[\mathrm{O}_{2}\right]} \\
& K_{X}=\frac{\left[\mathrm{CoL} \cdot \mathrm{H}_{2} \mathrm{AB}\right]\left[\mathrm{O}_{2}\right]}{[\mathrm{CoL}]\left[\mathrm{H}_{2} \mathrm{AB}\right]\left[\mathrm{O}_{2}\right]} \\
& K_{X}=\frac{\left[\mathrm{CoL} \cdot \mathrm{H}_{2} \mathrm{AB} \cdot \mathrm{O}_{2}\right]}{\left[\mathrm{CoL} \cdot \mathrm{O}_{2}\right]\left[\mathrm{H}_{2} \mathrm{AB}\right]}
\end{aligned}
$$

From equation ( 12 ) and (14), the value of $\left[\mathrm{CoL} \cdot \mathrm{I}_{2} \mathrm{AB} \cdot \mathrm{O}_{2}\right]$ is given by

$$
\left[\mathrm{CoL} \cdot \mathrm{H}_{2} \mathrm{AB} \cdot \mathrm{O}_{2}\right]=K_{N} K_{0}[\mathrm{CoL}]\left[\mathrm{O}_{2}\right]\left[\mathrm{H}_{2} \mathrm{AB}\right]
$$

The total concentration of the catayst $\left[\mathrm{Co}_{\mathrm{T}}\right.$ is given by equation (16)

$[\mathrm{Co}]_{\mathrm{T}}=[\mathrm{CoL}]-\left[\mathrm{CoL} \cdot \mathrm{O}_{2}\right]+\left[\mathrm{Col} \cdot \mathrm{H}_{2} \mathrm{AB}\right]+\left[\mathrm{CoL} \cdot \mathrm{H}_{2} \mathrm{AB} \cdot \mathrm{O}_{2}\right]$

Substituting the expressions for various catalyst containing species from equation (12). (13), and (14) yields equation (17)

$[\mathrm{CoI}]=\frac{[\mathrm{CoL}]_{T}}{\mathrm{l}+K_{0}\left[\mathrm{O}_{2}\right]+K_{\mathrm{A}}\left[\mathrm{H}_{2} \Lambda \mathrm{B}\right]+K_{K_{0}} K_{0}\left[\mathrm{ll}_{2} \Lambda \mathrm{B}\right]\left[\mathrm{O}_{2}\right]}$

Substituting equation (17) into equation (15) gives :

$\left|\mathrm{CoL}: \mathrm{II}_{2} \wedge \mathrm{B} \cdot \mathrm{O}_{2}\right|^{-}$

$$
\frac{K_{\mathrm{S}^{\prime}} K_{0}\left[\mathrm{Co}_{T}\left[\mathrm{H}_{2} \mathrm{AB}\right]\left[\mathrm{O}_{2}\right]\right.}{1+K_{0}\left[\mathrm{O}_{2}\right]-K_{X}\left[\mathrm{H}_{2} \mathrm{AB}\right]+K_{\mathrm{Y}^{\prime}} K_{0}\left[\mathrm{H}_{2} \mathrm{AB}\right]\left[\mathrm{O}_{2}\right]}
$$

The rate of azobenzene formation is derived from equation (11) and (18) :

$$
\mathrm{R}-\frac{\mathrm{d}[\Lambda \mathrm{B}]}{\mathrm{dt}}-\frac{K_{c} K[\mathrm{Co}]_{T}\left[\mathrm{H}_{2} \mathrm{AJ}\right]\left[\mathrm{O}_{2}\right]}{\mathrm{l}+K_{0}\left[\mathrm{O}_{2}\right]+K_{\mathrm{A}}\left[1 \mathrm{I}_{2} \Lambda \mathrm{B}\right]+K\left\lfloor\mathrm{l} \mathrm{I}_{2} \Lambda \mathrm{B}\right\rfloor\left[\mathrm{O}_{2}\right\rfloor}
$$

, where $K=K_{*}^{\prime} K_{i}$. The constants are best determined by a plot of $1 / k_{0}$ versus $1 /\left[\mathrm{H}_{2} \mathrm{AB}\right]$ from equation $(20)$ :

$$
\frac{1}{k_{0}}=\frac{1}{\left[1 \mathrm{I}_{2} \Lambda \mathrm{B}\right]}\left(\frac{K_{0}}{k_{c} K}+\frac{\mathrm{l}}{k_{\mathrm{L}} K\left[\mathrm{O}_{2}\right]}\right)+\frac{1}{k_{c}}\left(1+\frac{K_{N}}{K\left[\mathrm{O}_{2}\right]}\right)
$$

where $k_{o}=\mathrm{R} /[\mathrm{Co}]_{\mathrm{r}}$ and $K=K_{i} K_{o}^{\prime}=K_{0} K_{s}^{\prime}$. The intercept

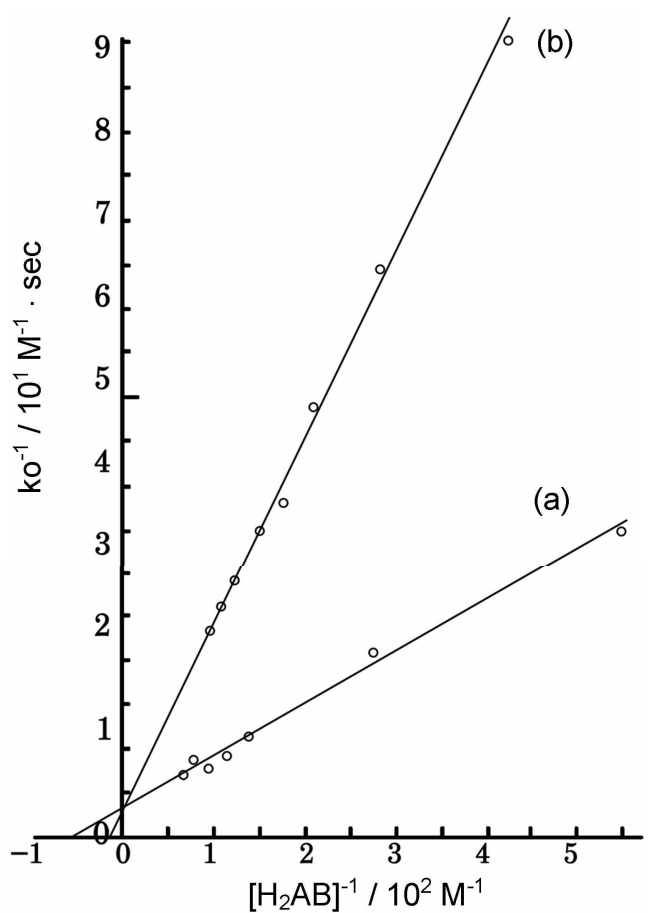

Figure 14. Plots of $k_{0}{ }^{\prime}$ against $\left[H_{2} \wedge B\right]_{0}$. Curve (a) $O_{2}$ saturated, Curve (b) air saturated, Methanol, 1 atm, $25^{\circ} \mathrm{C}$. [Co]r $-7.30 \times$ $10^{-11} \mathrm{M}$.

on the $1 / k_{0}$ axis is :

$$
\frac{1}{k_{o}}=\frac{1}{k_{c}}\left(1+\frac{K_{N}}{K\left[\mathrm{O}_{2}\right]}\right)
$$

This is only independent of [ $\left.\mathrm{O}_{2}\right]$ if $K_{\mathrm{N}}$ is zero. The slope of the plot of $1 / k_{0}$ versus $1 /\left[\mathrm{H}_{2} \mathrm{AB}\right]$ is :

$$
\frac{k_{o}}{k_{c} K}-\frac{1}{k_{c} K\left[O_{2}\right]}
$$

and it sheruld decrease to a limiting value as the oxygen concentration is increased.

If the kinetic scheme is correct, we expect that plot of the

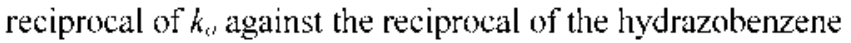
concentration at constant $\left[\mathrm{O}_{2}\right]$ will be linear in accordance with equation (20). Figure 14 shows that the plots are linear and it is noteworthy that the plots for different $O_{2}$ concentrations should intersect at a single point, with $\left[\mathrm{H}_{2} \mathrm{AB}\right]^{-1}=$ $-K_{\lambda}$. The intersection point lies within experimental error on the vertical axis. This indicates that the reaction via the binary complex cobalt $\mathrm{H}_{2} \mathrm{AB}\left(\mathrm{CoL} \cdot \mathrm{H}_{2} \mathrm{AB}\right)$ does not occur and the value of $k_{C}$ may be read from the intersection point, while the slopes of the two lines gives $K_{o}$ and $K$. Values of rate and equilibrium constants, with estimated limits of error, are shown in Table 12. The kinetic studies show that a ternary complex $\mathrm{CoL} \cdot \mathrm{H}_{2} \mathrm{AB} \cdot \mathrm{O}_{2}$ is involved in the rate determining step.

Possible structures for the ternary complex $\mathrm{CoL} \cdot \mathrm{H}_{2} \mathrm{AB} \cdot \mathrm{O}_{2}$ include structure I, structure II, and structure III. To account for the hydrogen abstraction, the structure I with $\mathrm{N}-\mathrm{H}-\mathrm{O}$ bridging seems plausible. However, in a concerted reaction this would be expected to lead to cis-azobenzene, which was 

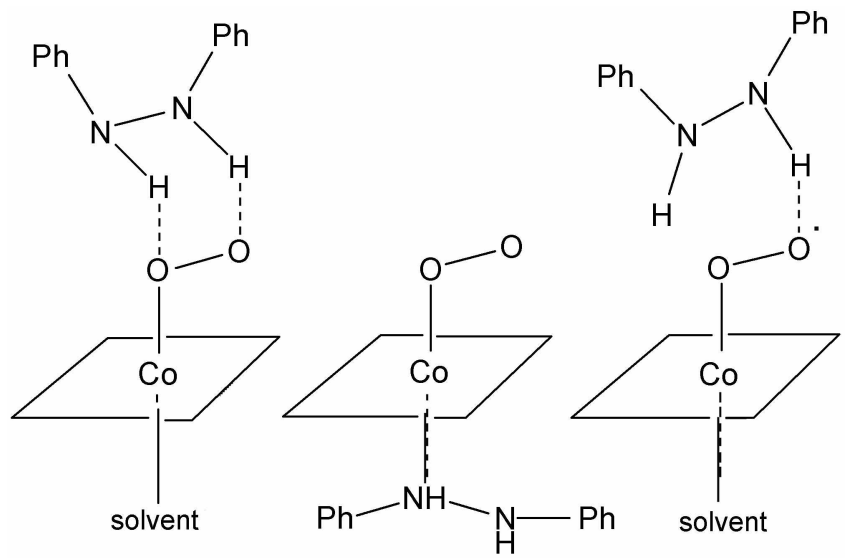

Structure I Structure II

Structure III

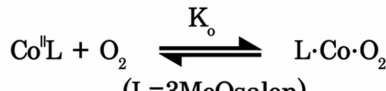

$$
\begin{aligned}
& \text { ( } \mathrm{L}=3 \mathrm{MeOsalen} \text { ) }
\end{aligned}
$$

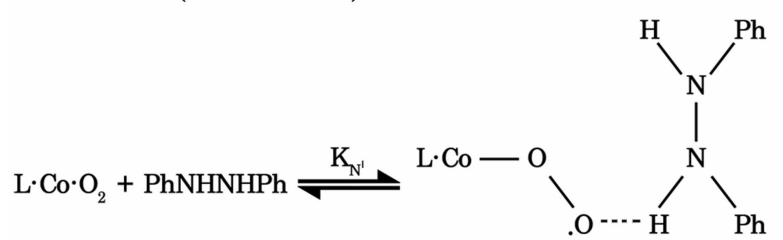

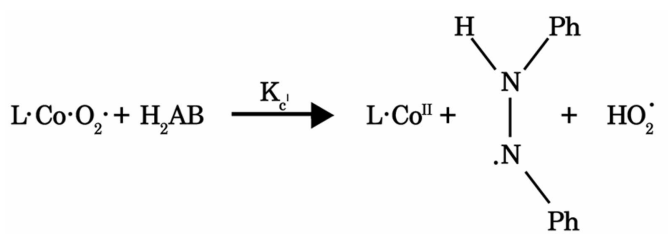<smiles>O[NH+](Nc1ccccc1)c1ccccc1</smiles>

$\mathrm{Ph}$

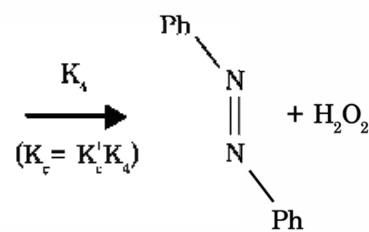

trans $-\mathrm{AB}$

$$
\mathrm{H}_{4} \mathrm{AH}+\mathrm{H}_{2} \mathrm{O}_{2} \stackrel{\mathrm{K}_{5}}{\longrightarrow} \mathrm{AB}+2 \mathrm{H}_{2} \mathrm{O}
$$

Figure 15. Proposed mechnism for the oxidation of hydrazobenzene by cobalt dioxygen catalyst $\mathrm{Co}(3 \mathrm{MeOsalen})\left(\mathrm{O}_{2}\right) .{ }^{32}$

not observed. The isomerisation of cts-azobenzene to the trans isomer was also followed at $315 \mathrm{~nm}$, and the reaction rate was very slow and was not catalysed by $\operatorname{Co}(3 \mathrm{Me}$ Osalen).

The first order rate constant for the isomerisation was found to be $1.28 \times 10^{-6} \mathrm{sec}^{-1}$ which is much smaller than the rate constant $\left(3.33 \times 10^{-4} \mathrm{sec}^{-1}\right)$ for the oxidation of hydrazobenzene calculated from Figure 8 . Thus cisazobenzene could not have been the initial product. Structure $\mathrm{II}$ is not necessarily the effective reaction intermediate. The situation in which an association complex is detected, but some other species of the same composition, but relatively less stable, is the true reaction intemediate, is paralled in

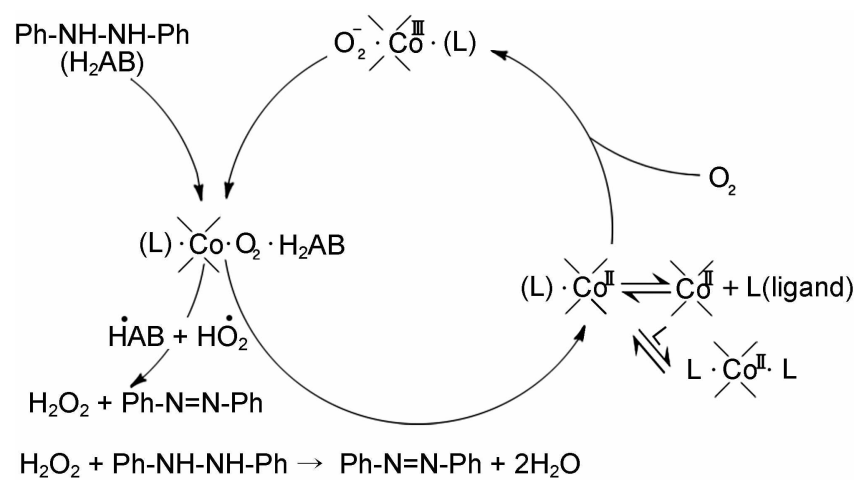

Figure 16. Catalysis cycle for $\mathrm{Co}(3 \mathrm{MeOsalen})$ catalysed oxidation of hydrazolenzene, [ $\left.\mathrm{H}_{2} \mathrm{AB}\right]$ by molecular oxygen. $?$ ?

many other reactions e.g. electron transfer by the "dead-end' mechanism. ${ }^{2{ }^{2}}$ The most reasonable intermediate is structure III. Drago's group proposed hydrogen bonding to the terminal oxygen of the bound dioxygen molecule because the terminal oxygen has more of the unpaired electron density on it. ${ }^{30}$ The upper limit of $K_{X}$ is estimated as $10^{-1} \mathrm{M}^{-}$ ${ }^{1}$ while $K_{\mathrm{A}^{\prime}}^{\prime}=K / K_{0}=172 \mathrm{M}^{-1}$. The difference and be understood if the $\mathrm{d}_{12}$ electron in the complex is partially delocalised onto the $\mathrm{O}_{2}$ molecule, so that the effective oxidation state of cobalt is intermediate between Coll and $\mathrm{Co}^{\mathrm{II}}: 2 \mathrm{~s}$

The proposed mechanism is shown in Figure 15. The polar solvent, methanol, coordinates to the cobalt(II) complex and affects the electron density of the $\mathrm{d}_{22}$ orbital of cobalt, increasing the charge on the dioxygen moicty, equation (a). This cause the abstraction of the hydrogen atom, equation (c). The $\mathrm{N}-\mathrm{H}-\mathrm{O}$ bridging structure III and equation (b) are analogous to that suggested by Savitskii" for isopropanol oxidation and by Beckett ${ }^{\text {il }}$ for the 1-phenylethanol oxidation reaction. After abstraction of the hydrogen atom, radicals "HAB and $\mathrm{HO}_{2}$ (hydroperoxy), may be lomed, equation (c), and the catalyst regenerated. The formation of the $\mathrm{HO}_{2}{ }^{\circ}$ and $\mathrm{HAB}$ radicals also agrees with Irago's mechanism ${ }^{15}$ for the catalysed oxidation of phenol. If cis-HAB' is formed in step (b) it could rearrange rapidly to the trans form by rotation about the N-N bond before reacting with $\mathrm{HO}_{2}{ }^{\circ}$ to produce trans-azobenzene and hydrogen peroxide. According to Beckett and Homer's $\mathrm{s}^{2]}$ proposal, in a related system, the hydrogen peroxide may affect further oxidation of substrate and produce azobenzene and water. The reactions are summarised in the catalytic cycle, Figure 16.

\section{Experimental Section}

$\mathrm{H}_{2}$ (3MeOsalen) was prepared by the method of Diehl et of ${ }^{11} 3$-methoxysalicylaldehyde $(35.5$ mmoles) was dissolved in hot absolute ethanol $(25 \mathrm{~mL})$ and the solution stirred for 30 minutes ethanol. Yield $72 \%, \mathrm{mp} 162-163^{\circ} \mathrm{C}$, as reported. Elemental analysis based on $\mathrm{C}_{1 \times} \mathrm{H}_{20} \mathrm{~N}_{2} \mathrm{O}_{4}$ : calculated C: $65.9, \mathrm{~N}: 8.5, \mathrm{H}: 6.1$; found: $\mathrm{C}$ 65.6, . : 8.4, H: 6.2.

The catalyst Col(3MeOsalen), was prepared by the method of Diel $\mathrm{et} a .{ }^{33}$ as modified by Beckett. ${ }^{31}$ The ligand, 
$\mathrm{H}_{2}$ (3MeOsalen) (35.5 mmoles) was dissolved in absolute ethanol $(300 \mathrm{~mL})$ and cobalt(II) acetate tetrahydrate (35.5 mmoles) was dissolved in hot water under nitrogen and added dropwise to the solution of the ligand. The pink solution changed to dark red. After cooling, a silver gold precipitate was formed. The product was filtered, washed with ethanol $(30 \mathrm{~mL})$ and then water $(30 \mathrm{~mL})$, and finally dried in vacua at $180^{\circ} \mathrm{C}$ for at least two hours. The colour of the product changed from silver gold to violet. Yield $52 \%$. Elemental analysis based on $\mathrm{COO}_{4} \mathrm{~N}_{2} \mathrm{C}_{18} \mathrm{H}_{15} \mathrm{O}_{2}$ : calculated: C: $51.80, \mathrm{H}: 4.36, \mathrm{~N}: 6.71$; found: C: $52.15, \mathrm{H}: 4.74, \mathrm{~N}: 6.87$.

Hydrazoberzene (Aldrich) was always kept in a dry nitrogen glove bag. Dry nitrogen was produced by passing cylinder nitogen over $\mathrm{P}_{2} \mathrm{O}_{5}$, Oxygen saturated reaction mixtures were made by bubbling oxygen through the solution for fifteen minuetes.

The rates of the reactions were followed by observing absorbance changes against time in the reaction mixtures at a wavelength of $325 \mathrm{~nm}$ or $437 \mathrm{~nm}$ in $1 \mathrm{~cm}$ cells. The reactions were conducted at a terfold molar excess or more of hydrazobenzene over the cobalt(II) complex. The absorption spectra were measured on a Pye Unicam SP8-200 spectrophotometer.

Achnowledgment. This work was supported by grants from the University of Ulsan, British Council, Piaris $\mathrm{Co}_{\text {, }}$ Ltd, and the Korea Science and Engineering Foundation. We wish to thank Professor S. F. A. Kettle for helpful discussions.

\section{References}

1. (a) Pfiffer. P.: Breith. E.: Lubbe. E.: Tsumaki. T. Jistils Liebios Ann Chem. 1933, 503, 84. (b) Kim, H. V.; Lee, H. K.; Lee, S. W. Bull. Korean Chem. Soc, 2005, 2666), 892. (c) Lee, V. H.; Byun, I. C.; Oh, T.-H. Bull. Korean Chem. Soc. 2005, 26(3), 454.

2. Tsumaki, T. Bull. Chem. Soc. Jph. 1938, I3, 252.

3. Jones, R. D.; Summerville, D. A.; Basolo, F. Chem. Rev. 1979, 79, 139.

4. Perutz, M. F. Brit. Med. Bull. 1976, 32, 195.

5. Adduci, A. T. Chemtech, 1976, 6,575.

6. Marlell, A. E.; Niederhoffer, E. C. J. H.; Timmons, J. H. Chem.
Rev: 1984, 84, 137 .

7. Sinith, T. D.; Pilbrow, J. R. Coord. Chem, Rer. 1981, 39, 295.

8. Drago, R. S.; Corden, B. B. Ace Chem. Res 1980, /3, 353.

9. Savitskii, A. V.J. Gen. Chent. USSR 1974, 44, 1518.

10. Zombeck, A.: Drago, R. S.: Corden, B. B.: Gaul, J. H. J. Am. Chem. Soc. 1981, 103,7580.

11. Nishinaga, A. Chem. Lett. 1975, 273

12. Martell, A. E.; Bedell, S. A. Inoms. Chent. 1983, 22, 364.

13. (a) Savitskii, A. V.; Nelvubir, V. I. J. of General Chem of the USSR 1979, 49, 2028. (b) Kim, J. C.: Lough, A. J. Bull. Koream Chem. Soc. 2005, 26(1), 169.

14. (a) Nishinaga, A.; Tonita, H.; Nishizawa, K.; Matsuura, T. $J$. Chen. Soc. Dathon 1985. 107.2903. (b) Lee, J.; Choe, J.-I.; Jung. S.; Ham, S. W. Bull, Korew Chem, Soc, 2006, 27(1), 33.

15. Drago, R. S.; Corden, B. B.; Perito, R. P. J. Am. Chem. Soc 1985, 107,2903

16. (a) Drago, R. S.: Zombech, A.: Hamilton, U. E. J. Am. Chem. Soc. 1982, 104, 6782. (b) Cho, C. S.: Kim, D. Y.; Shim, S. C. Bull. Korean Chem. Soc 2005, 26(5), 802 .

17. Simandi, L. I.; Nemeth, S.; Szeverenyl, Z. Irorg. Chim. Acto 1980, 44, L107.

18. Manchot, W.; Herzog, J. Jistits Liebigs Ann. Chem. 1901, 3/8, 331.

19. Walton, J. H.: Filson, G. W. J. Am. Chem. Soc. 1932, 94,3228 .

20. Kaupp, G.; Russell, G. A. Chem. Ber: 1968, 101, 1729.

21. Homer, R. B.; Beckett, M. A. Inorg. Chim. Act 1986, /15, L25.

22. Waters, W. A. Mechoni of Oxidation of Organic Compourds; Wilev: London, 1964.

23. Kochi, J. K.: Sheldon, R. A. Ad: Cafal. 1976, $25,272$.

24. Hinshelwood, C.; Blachadder, D. A. J. Chem. Phrs. 1957, 2898.

25. Wolf, A. J. Mol. Strikt 1980, 67,89.

26. (a) Jaffe, H. H.; Orchin, M. Theory and Applications of Ultraviolet Spectroscops; John Wiley: London, 1966; p 430. (b) Gerson, F.; Heilbronner, E.: Van-Veen, A.: Wepster, B. M. Heh: Chin. Acta $1960,43,1889$.

27. (a) Yamamoto, H.: Takayanagi, T.: Kwan, T. Bull. Chem. Soc. Jpn. 1975, 48, 2618. (b) Habibi-Yangjeh, A.; Nooshyar, M. Bttl. Korean Chem. Soc. 2005, 26(1), 139 .

28. Homer, R. B.; Camnon, R. D.; Kim, S. S. B. Bull. Korear Chent. Soc. $1985,6,115$.

29. Rosenheim, L.: Speiser, D.; Heim, A. Inorg. Chem. 1974, I3 1571.

30. Dori et al. J. Am. Chem. Soc 1975, 97, 3846.

31. Beckett, M. A., Ph. D. Thesis, University of East Anglia, 1981.

32. Kim, S. S. B., Ph. D. Thesis, University of East Anglia, 1987.

33. Diel, H.: Liggeth, L. M.: Hach, C. C.: Harrison, Gi C. lowa State Coll. Joum Scjence 1947, 22, 110. 